\title{
A cobertura jornalística das greves gerais de 2017: paradigma de protesto ou militância política
}

\author{
João Feres Júnior ${ }^{1}$ (i) \\ Marcia Rangel Candido 2 \\ Patricia Bandeira de Melo $^{3}$ \\ Lidiane Rezende Vieira 4 (iD
}

\section{Introdução}

O paradigma de protesto é um conceito amplamente utilizado pela literatura internacional nos estudos do tratamento dispensado pela grande mídia a manifestações políticas e sociais. Há três explicações para sua ocorrência: (1) varia com a orientação ideológica do meio (quanto mais conservador, maior a probabilidade de adotar o paradigma de protesto); (2) varia com a posição do protesto em relação ao status quo; e (3) nem sempre ocorre. Neste artigo analisamos a cobertura que a grande mídia brasileira dispensou às greves gerais de 2017 contra as reformas trabalhista e previdenciária, examinando os discursos e imagens associados aos grupos envolvidos nas greves gerais no Jornal Nacional e nos impressos Folha de S. Paulo, O Estado de S. Paulo e O Globo. Para tal utilizamos as metodologias da análise de enquadramento, interpretação de imagens e nuvens de palavras. Os resultados encontrados confirmam a ocorrência de paradigma de protesto nesses casos e revelam cinco modos predominantes de enquadrar as greves: (1) violência e vandalismo, (2) ação egoísta e desorganizada, (3) transtorno ao espaço público, (4) fonte de prejuízo à economia e (5) ausência de legitimidade popular. Na conclusão refletimos sobre a contribuição do presente artigo para o debate internacional sobre o assunto.

Palavras-chave: mídia; greves; reforma trabalhista; reforma da previdência; paradigma de protesto; governo federal

O segundo mandato de Dilma Rousseff se deu desde o seu início em uma atmosfera de alto conflito político, tanto nas ruas - com seguidas manifestações contrárias e

\footnotetext{
${ }^{1}$ Universidade do Estado do Rio de Janeiro. Instituto de Estudos Sociais e Políticos, Departamento de Ciência Política. Rio de Janeiro (RJ), Brasil. Universidade da Cidade de Nova York, Departamento de Ciência Política. Nova York (NY), EUA. Bolsista produtividade do CNPq, bolsista Cientista do Nosso Estado da Faperj, membro do Instituto da Democracia e da Democratização da Comunicação (INCT). Brasil. E-mail: $<$ jferes@iesp.uerj.br>.

2 Universidade do Estado do Rio de Janeiro, Instituto de Estudos Sociais e Políticos. Rio de Janeiro (RJ), Brasil. E-mail: <marciarangelcandido@gmail.com>. O presente artigo foi realizado com apoio da Coordenação de Aperfeiçoamento de Pessoal de Nível Superior - Brasil (Capes) - Código de Financiamento 001.

${ }^{3}$ Fundação Joaquim Nabuco. Recife (PE), Brasil; Instituto Universitário de Lisboa, Centro de Investigação e Estudos de Sociologia, Portugal. E-mail: <patricia.bandeira.melo@hotmail.com>.

4 Universidade do Estado do Rio de Janeiro, Instituto de Estudos Sociais e Políticos. Rio de Janeiro (RJ), Brasil. E-mail: <lidianerevieira@gmail.com>. Bolsista do CNPq - Brasil.
} 
favoráveis a seu impeachment - quanto no plano da política partidária - com renhido esforço do principal partido de oposição, PSDB, para anular o resultado eleitoral. No Congresso assistimos ao esfacelamento da base parlamentar da presidência e à formação de uma maioria pró-impeachment capitaneada pelo PMDB, outrora o principal aliado do PT na base, nas duas casas legislativas federais.

O sucesso das forças favoráveis à remoção de Dilma e à instalação de seu vice, Michel Temer, na presidência não pôs fim ao conflito político e não conseguiu resgatar a legitimidade das instituições perante a população. Partidos importantes que se juntaram ao PMDB no apoio ao impeachment, como PSB e PSDB, desembarcaram da coalizão ao longo do governo. Temer começou seu curto mandato com uma baixa taxa de aprovação popular, 26\%, e esta só fez declinar desde então, atingindo parcos $7 \%$ em setembro de $2017^{5}$. Ou seja, a crise política estava mais viva do que nunca, dentro e fora do governo.

A despeito disso, ou, talvez, justamente por assumir sua condição de "pato manco", Temer não hesitou em arcar com os custos de pautar como principais itens na agenda parlamentar de seu governo duas propostas que afetam particularmente a classe trabalhadora, as reformas trabalhista e previdenciária, além de outras iniciativas de feição neoliberal, como a privatização de empresas estatais e a redução de gastos com serviços públicos. É exatamente pelo fato de serem impopulares que tais reformas suscitaram, ou pelo menos deveriam ter suscitado, um acalorado debate público.

Em resposta à campanha pelas reformas de Temer, sindicatos, partidos de esquerda e movimentos sociais organizaram em 2017 duas greves gerais, em 28 de abril e 30 de junho. Para além de seus efeitos mais concretos e imediatos, a greve, e a greve geral em especial, é um evento que tem um objetivo comunicativo: ela visa fazer a insatisfação dos trabalhadores ser ouvida por toda a sociedade e pelo sistema político (Rucht, 1991).

Mesmo que sejam eventos com relativa limitação temporal, as paralisações representam momentos singulares de luta dos trabalhadores e são frequentemente utilizadas como uma das evidências fundamentais de análise dos movimentos sindicais (Boito Jr. e Marcelino, 2010; Cardoso e Gindin, 2017). Além disso, diferentemente de outros países onde as greves têm um sentido estritamente trabalhista, no Brasil, a proximidade entre as organizações sindicais e os demais movimentos sociais as investe de um caráter político mais amplo, como, no caso em questão, o combate às políticas neoliberais de Temer. De fato, as greves de 2017 permitiram observar a articulação entre distintos setores de esquerda, seja a partir do material de divulgação de movimentos sociais específicos, seja a partir das manifestações de organizações políticas que

\footnotetext{
5 Cf. <http://www6.sistemaindustria.org.br/gpc/externo/listaResultados.faces?codPesquisa $=121 \#>$. Acesso em: 11 dez. 2019.
} 
congregaram inúmeros grupos, a exemplo da Frente Brasil Popular e da Frente Povo Sem Medo 6 .

Contudo, para ter efetividade comunicativa, que, em outras palavras, redunda em angariar legitimidade e apoio popular às suas demandas, os movimentos grevistas dependem dos meios de comunicação. É claro que o adjetivo "geral" dá a entender que a paralisação ocorre em todas as partes e que, portanto, o sucesso da mobilização é em si um sinal do acolhimento das demandas por parte do público. Na prática, porém, tais movimentos raramente conseguem mobilizar toda a sociedade. Isso faz com que dependam da imprensa para chegar a parcelas da população não atingidas pelas ações coletivas. Ademais, a paralisação é sempre um momento fugidio, e a mídia é capaz de formular interpretações e argumentos que infundem significado ao ato. Ou seja, sempre em seguida a um evento desse porte há uma disputa pela interpretação de seu significado, e essa disputa se dá em boa medida na grande imprensa. Estudos de recepção mostram que a maneira como a mídia representa manifestações e manifestantes tem influência sobre o modo como o público julga seu comportamento e demandas e, por conseguinte, sobre sua legitimidade e apoio popular (Lipsky, 1968; Gamson e Wolfsfeld, 1993; McLeod, 1995; McLeod e Detenber, 1999; Detenber et al., 2007). Alguns autores chegam a argumentar que o enquadramento midiático dado aos movimentos afeta diretamente suas chances de sucesso (Snow et al., 1986; Benford e Snow, 2000).

O objetivo deste artigo é analisar a cobertura da grande mídia em relação às greves gerais ocorridas em 28 de abril e 30 de junho de 2017 contra as reformas trabalhista e previdenciária. Mais especificamente, pretendemos avaliar a pertinência do uso do conceito de "paradigma do protesto" para entender o comportamento da grande mídia brasileira perante esses eventos. Como os meios de comunicação com maior circulação no país traduziram as greves gerais ao público? Quais estratégias de mediação as empresas de jornalismo mobilizaram? Quais pontos de vista foram publicados? Como os movimentos sociais envolvidos foram representados? Para responder a tais questões, além desta Introdução, o texto é dividido em quatro partes. Na primeira, "Estudos de mídia e protesto no Brasil", fazemos uma breve revisão bibliográfica do tema da mídia e da cobertura de protestos no país. Em seguida, em "O paradigma de protesto", examinamos a literatura internacional sobre o conceito e identificamos suas principais teses. Na sequência, em "Metodologia", esclarecemos como foi feita a análise, combinando métodos quantitativos e qualitativos, com o uso do programa NVivo9. Na quarta parte, em "Resultados", analisamos os discursos e imagens associados aos grupos envolvidos nas greves gerais no Jornal Nacional (JN) e nos impressos Folha de S. Paulo (Folha), O Estado de S. Paulo (Estadão) e $O$ Globo, combinando técnicas de análise de enquadramentos, interpretação de imagens e nuvens de palavras. Por fim, em "Avaliação geral dos resultados", discutimos

\footnotetext{
6 Ver movimentos que integram a Frente Brasil Popular em: <http://www.frentebrasilpopular.org.br/conteudo/organizacoes-participantes/>, e Frente Povo Sem Medo em: <https://pt.wikipedia.org/wiki/Frente_Povo_Sem_Medo>. Acesso em: 11 dez. 2019.
} 
os dados provenientes da análise, refletindo acerca da produtividade do uso do conceito de paradigma de protesto para o caso brasileiro.

\section{Estudos de mídia e protesto no Brasil}

Diversos estudos mostram que a prática da grande imprensa brasileira frequentemente contraria sua declarada posição de neutralidade e isenção, apresentando comportamento fortemente enviesado em relação aos representantes políticos, aos partidos e aos diferentes temas que noticia, e que esse viés adquire caráter pronunciadamente negativo no tratamento dado à esquerda e a seus representantes. Tal comportamento foi capturado pela literatura em todos os períodos eleitorais da Nova República (Albuquerque, 1994; Aldé, Mendes e Figueiredo, 2007; Azevedo, 2017; Boas, 2005; Feres Júnior e Sassara, 2016; Kucinski, 1998; Lima, 2001; Miguel, 1999, 2002; Miguel e Biroli, 2011; Rubim e Universidade Federal da Bahia, 2000; Rubim e Azevedo, 1998), com a provável exceção do pleito de 2002. Mesmo assim, alguns autores detectaram viés na cobertura do Jornal Nacional daquele pleito em favor do governo Fernando Henrique Cardoso (PSDB) (Miguel, 2004; Porto, 2007).

Há de fato um exército de autores que, ao longo das eleições presidenciais da Nova República, por meio do uso de metodologias variadas como análise de conteúdo, análise de valência, análise de enquadramento, análise de agendamento etc., detectaram forte viés da grande mídia brasileira contra os candidatos de esquerda e seus partidos, mormente Luiz Inácio Lula da Silva, do Partido dos Trabalhadores (PT). As poucas vozes que destoaram desse diagnóstico o fizeram em contextos e por razões bastante específicas. Matos (2008) e Porto (2012) publicaram livros para uma audiência internacional nos quais argumentavam que estava em curso na década de 2000 um processo de democratização da mídia brasileira, com maior abertura das redações para a sociedade civil e maior equilíbrio na cobertura política das eleições. Ambos os autores foram visivelmente impactados pela eleição de 2002, que foi relativamente atípica pelo baixo nível de politização e de viés da cobertura midiática. Ademais, não poderiam prever a politização crescente da cobertura nas eleições de 2010 e 2014, ainda que Porto levantasse a possibilidade de regressão no processo de democratização que imaginava ver na Rede Globo, particularmente ao comentar en passant a cobertura da eleição presidencial de 2006, que de fato não entrou no seu escopo de análise. Demonstrando coragem e lisura acadêmica, Porto reconheceu publicamente o equívoco de seu diagnóstico em seu discurso de abertura da Compolítica de 2019, no Rio de Janeiro.

A última voz que é por vezes tomada como destoante da literatura de mídia e política é a de Pedro Mundim. Depois de passar boa parte de sua carreira publicando textos que detectavam viés midiático sistemático contra a esquerda (Bezerra e Mundim, 2011; Mundim, 2010, 2012, 2014), o autor publicou artigo em que parece colocar essa tese sob suspeita (Mundim, 2018), ainda que os dados que ofereça como evidência mostrem o 
contrário. Na verdade, Mundim pretende refutar a tese de que a grande mídia brasileira, isto é, os jornais $O$ Globo, Folha e Estadão, age em bloco. Ele de fato mostra que o viés antipetista varia de eleição para eleição e de meio para meio, mas ao mesmo tempo está presente de maneira bastante pronunciada em todas as eleições que analisa (2002, 2006 e 2010).

Devemos intuitivamente esperar que essa orientação política dos meios tenha impacto sobre a maneira como eles cobrem eventos como as greves gerais, uma vez que estas são quase sempre produto da ação de organizações políticas de esquerda. Contudo, é preciso notar que o foco da literatura acadêmica recai sobre o comportamento da imprensa durante períodos eleitorais. São raros os trabalhos que tratam da cobertura jornalística da política fora das eleições.

Os estudos sobre movimentos sociais, por sua vez, ganharam grande impulso depois das manifestações de junho de 2013. Entretanto, são escassas as publicações nesse campo que tratam das relações entre a mídia e os movimentos. As parcas análises que enfrentam o problema raramente circulam em meios científicos bem qualificados no sistema de avaliação nacional ${ }^{7}$. Textos em anais de congressos e em periódicos de credibilidade não certificada são sinais inequívocos da menor maturidade do tema nas áreas das ciências sociais e da comunicação ${ }^{8}$.

A produção acadêmica existente, que já não é abundante, privilegia a representação dos movimentos sociais construída nos textos jornalísticos e não propriamente o tratamento dispensado pela mídia aos eventos de protesto. O Movimento dos Trabalhadores Rurais Sem Terra (MST), por exemplo, passou a ser, a partir dos anos 1990, um dos atores coletivos mais estudados no país (Bringel, 2014) e também no exterior (Gohn, 2014). Tais trabalhos invariavelmente revelam aspectos bastante negativos da cobertura que os meios dedicam ao MST, marcada por elementos como: (1) intenção clara de criminalização do movimento, (2) relatos que destoam bastante daqueles que o MST veicula em suas mídias independentes, (3) ênfase na violência e na radicalidade, a despeito das pautas defendidas nas ações do movimento e (4) ínfimo espaço dado à voz dos militantes e a suas demandas (Ayoub, 2007; Comparato, 2001; Mourão, 2011; Reis, 2011; Cruz, 2012; Souza e Silva, 2013).

Em suma, há uma lacuna no debate acadêmico no que toca à análise de dados empíricos sobre a cobertura midiática dos eventos de protesto no Brasil, bem como ao desenvolvimento de formulações conceituais e teóricas sobre o tema. Na literatura internacional, por outro lado, estudos sobre a interação entre meios de comunicação e movimentos sociais são abundantes, particularmente no que toca a manifestações de massa (Boyle e Armstrong, 2009; Boyle et al., 2004, 2005; Dardis, 2006; Gitlin, 1981).

\footnotetext{
7 Publicações em periódicos bem qualificados são os indícios mais utilizados na literatura acadêmica para avaliar o desenvolvimento das áreas e subáreas do conhecimento. Ver, por exemplo, os capítulos do livro comemorativo da Associação Brasileira de Ciência Política, que faz um balanço da institucionalização da disciplina ao longo das últimas décadas (Avritzer, Milani e Braga, 2016).

8 Os poucos trabalhos encontrados foram publicados nesses formatos. Ver, por exemplo: Mourão, 2011; Moabis, 2014; Meneses, 2014.
} 
Nessa literatura, o conceito de "paradigma de protesto", que discutiremos a seguir, tem papel central.

\section{O paradigma de protesto}

Uma das discussões mais desenvolvidas acerca da relação entre meios de comunicação e política em periódicos científicos e livros estrangeiros diz respeito ao conceito analítico de paradigma de protesto formulado originalmente por Joseph $\mathrm{M}$. Chan e Chi-Chuan Lee para estudar manifestações populares e greves de fome contra o fechamento da escola secundária Precious Blood Golden Jubilee, em Hong Kong, na década de 1970 (Chan e Lee, 1984). Os autores advogam a tese de que os jornais cobrem manifestações de acordo com suas inclinações ideológicas, publicando seletivamente o que Ihes interessa nos protestos. Enquanto jornais de direita apresentaram o movimento como uma ameaça à ordem e ao status quo, os jornais de esquerda tenderam a dar mais voz às demandas dos manifestantes.

O conceito de paradigma de protesto foi em seguida incorporado pelos estudos sobre a mídia norte-americana, que se diferencia do caso de Hong Kong por reclamar para si própria um alto grau de profissionalismo e isenção jornalística. Os primeiros estudos produzidos focaram quase que exclusivamente os movimentos de "esquerda" (direitos civis, movimento contra a guerra no Vietnã, altermundistas etc.) e identificaram a mesma tendência da imprensa estadunidense de descrever tais fenômenos como ameaças ao status quo, um padrão associado a jornais de direita em Hong Kong (Gitlin, 1981; McLeod e Detenber, 1999; Boyle et al., 2004; Dardis, 2006).

McLeod descreve o paradigma de protesto como uma prática narrativa da imprensa composta por: (1) enquadramentos seletivos de exposição dos fatos e consulta a fontes oficiais que frequentemente se contrapõem às reivindicações dos manifestantes, (2) menções à opinião pública como oposta às manifestações, (3) deslegitimação das demandas e (4) demonização dos grupos envolvidos (McLeod, 2007). Contribuindo para qualificar ainda mais o conceito, Smith et al. (2001) argumentam que as manifestações progressistas são marginalizadas e o foco da cobertura recai sobre os manifestantes em si e não sobre seus motivos e aspirações. Dardis (2006) vai além ao postular que a estratégia de marginalização adotada pelo jornalismo dá relevo à aparência e às habilidades mentais dos manifestantes e faz uso de todo tipo de fonte de legitimidade (estatísticas, senso comum, testemunhos) para desacreditar os movimentos. Outros autores identificam recursos adicionais rotineiramente empregados pela mídia para cobrir manifestações públicas de massa que caracterizam o paradigma de protesto, como enfoque na violência, espetacularização dos episódios de protesto, difusão da ideia de manifestantes como desviantes sociais, promoção da percepção de dissenso interno aos movimentos e trivialização das propostas em questão (Gitlin, 1981; Ashley e Olson, 1998; Xu, 2013). 
Mas tal representação pejorativa não é constante. Em um esforço de sofisticação do paradigma de protesto, Shoemaker (1984) argumenta que, quanto mais radical é o movimento, mais negativa é a cobertura da grande mídia (mainstream media). Tal tese é matizada por McLeod e Hertog (1999), segundo os quais a radicalidade do movimento é diretamente proporcional à propensão da mídia de aderir ao paradigma de protesto. Em outras palavras, segundo esses autores, o extremismo dos objetivos e das táticas utilizadas por movimentos e militantes são determinantes no modo como os meios de comunicação reproduzem ou não o paradigma de protesto. Quando os manifestantes possuem causas alinhadas às elites políticas ou às normas dominantes, eles não se encaixam nesse tipo de construção narrativa (McLeod, 2007). Isso sugere que a intensidade de enquadramentos favoráveis ou contrários desenvolvidos pelos jornalistas varia conforme os atributos e as relações dos movimentos sociais. O trabalho de Ashley e Olson (1998) parece confirmar essa postulação. Ao compararem a cobertura dos grandes jornais estadunidenses sobre movimentos sociais opostos - feministas e antifeministas -, as autoras ponderam que, embora ambos encontrem pouco espaço na mídia, as antifeministas são retratadas como mais organizadas e atrativas, em contraste claro com a imagem apresentada das feministas.

Diversos estudos contribuem para expandir ainda mais a identificação de mecanismos que formatam a produção de notícias acerca de manifestações de massa. A noção de paradigma de protesto tem servido de base para análises do comportamento de sistemas de mídia em países com realidades bastante distintas. Trabalhos sobre Eslovênia (Trivundža e Brlek, 2017), Espanha e Grécia (Kyriakidou e Olivas Osuna, 2017), China (Lee, 2014; Shahin et al., 2016), México (Harlow et al., 2017), Brasil e Índia (Shahin et al., 2016) e Egito (Harlow e Johnson, 2011) sinalizam a internacionalização e difusão do conceito e a tentativa de investigar se certas tendências dos grandes meios noticiosos notadas pelos primeiros teóricos do paradigma de protesto são partilhadas globalmente.

Assim como as análises sobre os Estados Unidos acima citadas, parte desses trabalhos conclui que nem sempre o paradigma de protesto é reproduzido pela grande mídia. Kyaruakidou e Olivas Osuna (2017), por exemplo, analisam a cobertura do 15-M na Espanha e dos Indignados na Grécia e apontam para um viés relativamente positivo de reportagens, sem ênfase na violência, mesmo que as pautas das manifestações sejam contrárias ao status quo. Perfil diferenciado de militantes, proliferação de novos meios de comunicação e distintas filiações políticas dos meios ajudam a matizar a adequação do termo (Weaver e Scacco, 2013; Lee, 2014; Harlow et al., 2017; Kyriakidou e Olivas Osuna, 2017; Trivundža e Brlek, 2017).

Quando citamos anteriormente a quase inexistência de trabalhos sobre esse tema no Brasil, nos referíamos à produção de autores divulgada em revistas acadêmicas nacionais. Há de fato uma pesquisa sobre o paradigma de protesto que compara Brasil, China e Índia feita por Saif Shahin, Pei Zheng, Heloisa Sturm e Deepa Fadnis. As autoras chamam atenção para a dificuldade de aplicar um mesmo conceito a contextos diversos e 
declaram que é necessário ter cautela para não transpor noções de modo acrítico e estático. A conclusão geral do estudo é que algumas características do paradigma de protesto podem ser verificadas em realidades distintas, enquanto outras não (Shahin et al., 2016).

No que toca ao Brasil, Shahin et al. (2016) postulam, a partir da observação das notícias sobre as manifestações de junho de 2013, que a mídia brasileira se encaixa no paradigma de protesto de forma moderada: menciona frequentemente a violência como advinda dos manifestantes e consulta majoritariamente fontes oficiais - instituições do governo etc.; ao mesmo tempo, não deixa de expor as causas dos protestos, nem deslegitima suas pautas. O material analisado foi composto da cobertura dos jornais $O$ Globo e Folha, escolhidos devido a suas supostas posições políticas distintas - o primeiro conservador e o segundo progressista (Shahin et al., 2016).

A análise do contexto brasileiro, no entanto, nos parece bastante deficiente: em primeiro lugar, apesar de mencionar que os objetivos das Jornadas de Junho se alteraram ao longo do tempo - de fato, as reivindicações iniciais contra o aumento das passagens de ônibus se diluíram em uma cacofonia de demandas difusas e conflitivas -, o trabalho não apreende de que forma esse processo poderia estar relacionado a alterações na cobertura midiática.

Outro problema é que uma das considerações finais das autoras afirma que o "paradigma de protesto" é mais fácil de ser encontrado em países nos quais o governo e a imprensa partilham posições ideológicas. No Brasil, o caráter de centro-esquerda do governo Dilma Rousseff, então em voga, é mencionado como fator que possibilitou à Folha, qualificada como progressista, se aproximar mais do "paradigma de protesto". Ou seja, apresentar um viés contrário às manifestações que eram opostas ao governo. O problema dessa afirmação é que diversas pesquisas acadêmicas mostram que as mídias impressas de maior circulação no país, inclusive a Folha, foram severamente antagônicas aos governos do Partido dos Trabalhadores e a Dilma Rousseff ${ }^{9}$. A hipótese de "afinidade ideológica" entre o governo Rousseff e a Folha é francamente insustentável.

Não é nosso objetivo principal aqui questionar diretamente as teses de Shahin et al. sobre o comportamento da grande mídia brasileira perante as manifestações de junho de 2013, nem tampouco a contestável classificação da Folha como jornal progressista. Pretendemos, sim, testar a tese das autoras para o caso da cobertura das greves gerais de 2017, na forma da seguinte pergunta:

1. É possível dizer que no caso em pauta o paradigma de protesto moderado, identificado por Shahin et al., se verifica?

Tomando como base a revisão da literatura internacional sobre o conceito de paradigma de protesto, gostaríamos também de tentar responder à seguinte questão:

2. O paradigma de protesto ocorre no Brasil de modo similar ao observado no estudo original de Hong Kong (mídias ideológicas com conservadores se posicionando

\footnotetext{
${ }^{9}$ Ver, por exemplo: Miguel e Biroli, 2011; Feres Júnior e Sassara, 2016; Azevedo, 2017.
} 
negativamente em relação aos protestos enquanto progressistas são mais favoráveis); segue o modelo norte-americano (mídia suspostamente profissional e isenta defendendo o status quo); ou não podemos observar qualquer um desses padrões, como alguns estudos mais recentes têm mostrado?

\section{Metodologia}

Neste artigo, utilizamos uma combinação de métodos quantitativos e qualitativos. A parte quantitativa consiste no uso de nuvens de palavras, produzidas pelo programa NVivo9, a partir de um corpus de todas as notícias publicadas nas capas e páginas de opinião das edições dos jornais Folha de S. Paulo, O Estado de S. Paulo e O Globo, e do conteúdo transcrito do Jornal Nacional, nos dias 27, 28 e 29 de abril de 2017 e nos dias 29 e 30 de junho e 10 de julho do mesmo ano - respectivamente, a véspera, a data e o dia seguinte de cada uma das paralisações.

A capa é a parte do jornal mais vista e, portanto, é desenhada para comunicar rapidamente as mensagens que os editores imaginam ser as mais importantes do dia para os consumidores ou para aqueles que miram os impressos de longe nas bancas de revista. Daí as letras garrafais das manchetes e as grandes fotos de impacto. As páginas de opinião contêm a posição do jornal nos editoriais e as percepções de colunistas e convidados, todas consentidas pelos editores do veículo. Ao analisarmos capas e páginas de opinião conjuntamente, somos capazes de avaliar o tratamento que o meio de comunicação dá ao tema tanto em suas principais reportagens do dia, anunciadas nas capas, quanto nos textos opinativos que publica.

A nuvem de palavras é uma técnica de visualização de listas de frequências. Após uma limpeza preliminar da base, retirando palavras muito frequentes mas com baixo teor semântico, como artigos, numerais, pronomes, preposições, advérbios etc., o programa compõe uma lista de frequência das palavras restantes e, em seguida, as representa graficamente, atribuindo a elas um tamanho proporcional a sua frequência na base. Essa técnica de representação permite que o leitor capte rapidamente o contorno semântico da base textual como um todo, algo difícil de ser alcançado com representações de dados mais detalhadas. No entanto, ela está aberta ao risco dos falsos positivos, isto é, de palavras salientes (grandes), que parecem coerentes com o todo, mas que na verdade são usadas nos textos com sentidos diferentes daquele que a nuvem sugere. Por isso complementamos essa análise quantitativa geral com uma análise de enquadramentos, de caráter qualitativo.

Derivada da sociologia de Goffman (1974), a análise de enquadramento foi apropriada pelos estudos de mídia de várias maneiras e para vários fins ${ }^{10}$. Com o objetivo

\footnotetext{
10 Para uma discussão mais aprofundada acerca da metodologia da análise de enquadramento (frame analysis), ver Campos (2014) e Mendonça e Simões (2012), com reflexões sobre sua recepção no Brasil, e Scheufele e Tewksbury (2007), Entman (1993) e Iyengar e Kinder (1987), para seus usos na academia de língua inglesa.
} 
de capturar os significados elaborados e difundidos na mídia acerca das duas paralisações, adotamos aqui a definição mínima e lapidar proposta por Robert M. Entman: "Enquadrar é selecionar alguns aspectos de uma realidade percebida e torná-los salientes" (Entman, 1993, p. 53) ${ }^{11}$. O aspecto hermenêutico dessa metodologia de análise semântica é óbvio, o que a aproxima bastante de várias vertentes da análise do discurso. Optamos por tal definição de enquadramento porque sua generalidade nos permite inclusive estender a análise às imagens, como elementos de reforço de significados presentes no texto ou mesmo de transmissão de outros significados que não estão nos textos mas que contribuem para a descrição narrativa do objeto.

Adotamos, para começar a análise, a lista de enquadramentos identificados por McLeod (2007) e, ao longo das leituras fomos revisando as codificações de maneira a produzir indutivamente enquadramentos mais apropriados para descrever o caso em questão, em um processo inspirado pela grounded theory ${ }^{12}$.

\section{Resultados}

A análise de textos e imagens evidenciou cinco modos predominantes de enquadramento das greves: (1) violência e vandalismo, (2) malandragem, ação egoísta e desorganizada, (3) transtorno ao espaço público, (4) fonte de prejuízo à economia e (5) ausência de legitimidade popular. A única impressão positiva acerca das duas greves emerge de forma pontual na publicação do Estadão e da Folha no dia 29 de abril da afirmação das centrais sindicais de que a paralisação de abril foi "a maior greve da história do país".

O sentido negativo relacionado às duas greves gerais é predominante nos textos. Na primeira paralisação há inúmeras alusões pejorativas às organizações sindicais e aos atos de mobilização, tais como "balbúrdia travestida de greve geral" (O Estado de S. Paulo, 29 de abril); "greve absurda convocada para amanhã e que está revoltando as pessoas ordeiras e de bem deste país" (idem); "sindicalistas são, na verdade, parasitas da contribuição sindical obrigatória" (idem); "querem com essa 'greve geral' de hoje atazanar de vez a vida da sociedade brasileira" (idem); "Greves e paralisações só prejudicam os cidadãos de bem que querem trabalhar" (Folha de S. Paulo, 28 de abril).

Como no paradigma de protesto clássico, a narrativa das pautas reivindicatórias dos movimentos sociais está ausente na cobertura. Não encontramos tentativas de síntese das questões que mobilizaram os trabalhadores e os distintos segmentos da militância. Em

\footnotetext{
11 No original: "[T]o frame is to select some aspects of a perceived reality and make them more salient". 12 A grounded theory é uma metodologia de inferência teórica muito usada em análises qualitativas de dados textuais. A ideia motriz é produzir, a partir da codificação mais desagregada possível do material, agregações semânticas que ganhem níveis crescentes de generalidade e, assim, produzir resultados que tenham potencial validade teórica. Seu caráter é fortemente indutivo, mas ela sempre depende de questões de pesquisa previamente colocadas, que vão aí orientar as agregações dos códigos, como no caso aqui dos enquadramentos dados pelos textos midiáticos às manifestações de apoio às greves. Para maiores detalhes sobre essa metodologia, ver Glaser e Strauss (1967), Corbin e Strauss (1990) e Ralph, Birks e Chapman (2015).
} 
raras ocasiões, alguns representantes de centrais sindicais foram consultados, mas apenas para comentários breves sobre as pautas dos jornais. É digno de nota, ademais, que integrantes de outros movimentos com relevante atuação relacionada às reformas não foram sequer mencionados.

O movimento feminista e o de trabalhadores rurais são casos relevantes a se observar: antes mesmo das greves gerais de abril e junho, o movimento feminista já havia convocado para o dia da mulher, 8 de março de 2017, uma greve geral de mulheres que tinha como mote a rejeição das reformas de Temer, com destaque para as consequências específicas que estas tinham sobre as jornadas de trabalho da população feminina e rural. O Manifesto - Movimentos de Mulheres Contra a Reforma da Previdência Social Convocam Lutas para o Mês de Março de 2017, por exemplo, reuniu distintas vertentes da militância feminista e se opunha veementemente à equiparação do tempo de contribuição à previdência entre homens e mulheres e trabalhadores rurais e urbanos. $\mathrm{O}$ argumento de que essas parcelas da população são mais vulneráveis e encaram rotinas de trabalho mais extensas passou longe de qualquer conhecimento dos espectadores e leitores dos grandes meios de comunicação (Amb, 2017). Por outro lado, o posicionamento oficial do governo federal foi amplamente coberto pelos jornais.

As sentenças pejorativas se repetem na segunda greve geral, mas a cobertura como um todo é menos intensa. Se, na primeira paralisação, foram feitas 58 referências à mobilização nas capas e primeiras páginas dos jornais, na segunda as ocorrências caíram para 14. Mais: na greve de abril, há 45 referências gerais à paralisação associadas a "vandalismo" e 18 vinculadas a "malandragem". Na greve de junho, com o arrefecimento da cobertura sobre as manifestações, o termo "malandragem" não tem frequência relevante nas narrativas e a expressão "vandalismo" e suas variações linguísticas somam cinco ocorrências. Isso será analisado em maior detalhe adiante, segundo as particularidades de cada um dos meios observados.

\section{O Globo}

Apesar de o jornal carioca ter dedicado uma seção especial do seu site ao tema "greve geral", a paralisação de abril não foi objeto de muita atenção nas capas e páginas de opinião da versão impressa. Das três edições analisadas, apenas em 29 de abril, dia seguinte à paralisação, há informações acerca do movimento de forma mais consistente. Na véspera da greve geral, uma chamada de capa do diário faz alerta ameaçador, replicado pelo Estadão, como vamos mostrar depois: "Michel Temer vai cortar o ponto dos servidores que aderirem à greve". No dia da greve, 28 de abril, a alusão ao movimento também vem na forma de alerta, dessa vez sobre o risco de falta de transporte público para a população, realçado em chamada na matéria de capa: "Greve ameaça afetar transportes".

Já em 29 de abril, O Globo dá manchete de capa para o episódio, mas o destaque recai sobre o transtorno causado no transporte e os supostos atos de vandalismo 
associados aos grevistas: "Protesto de centrais afeta transportes e tem violência". Abaixo do título, há um subtítulo condenando sindicalistas e repetindo o conteúdo da imagem do ônibus em chamas: "Sindicalistas bloqueiam vias e estradas; no Rio, ônibus foram queimados". Uma foto enorme, tomando aproximadamente um quarto da capa, mostra dois ônibus em chamas e a legenda começa com a palavra "vandalismo" em negrito, seguida do trecho: "Ônibus queimados no Centro do Rio, onde cinco pessoas ficaram feridas. Em São Paulo também houve violência e confronto entre manifestantes e policiais".

Logo abaixo da notícia que domina a capa, há um título pequeno que acompanha um texto curto de duas colunas: "Temer lamenta 'graves incidentes' no Rio e reafirma compromisso com reformas". O texto não fala quase nada sobre Temer, mas repete novamente que o protesto paralisou transportes e foi marcado por vandalismo e violência. Tal texto é ladeado com charge de Chico Caruso que mostra um ônibus em chamas e Temer ao lado.

É importante notar o uso retórico da repetição da mensagem. Na mesma capa, há cinco referências à queima de ônibus, três textuais e duas imagéticas, e três passagens atribuindo a responsabilidade aos sindicalistas. $O$ foco nos sindicalistas tem também a função de desqualificar o caráter "geral" da greve. A manchete chama o movimento de "Protesto de Centrais" e não de greve geral. Não bastasse isso, ao lado da charge, a capa anuncia artigo de Merval Pereira dizendo que não houve adesão popular à greve.

As páginas de opinião de $O$ Globo do dia 29 de abril trazem dois artigos relacionados à paralisação. Em ambos, explorou-se o sentido negativo da mobilização, sem espaço para outras possíveis perspectivas acerca do movimento. No editorial "A 'greve geral' das corporações", o jornal destacou que "a greve foi um espelho da resistência de corporações sindicais, e outras, a revisões cruciais para que a economia volte a crescer", quer dizer, a mobilização é apresentada como se animada por orientação contrária à retomada do crescimento econômico e pelo intuito de proteger direitos de poucos e não da massa de trabalhadores. Uma das páginas de opinião ainda contêm uma charge que mostra um sapo com a boca aberta, imagem que associa a greve de abril à luta por uma "boquinha", ou seja, por alguma vantagem indevida, ou malandragem, outro sentido recorrente nos periódicos estudados. Essa imagem, por sua vez, vem associada às delações de desvio em benefício de políticos do PT pela empresa Odebrecht.

$\mathrm{Na}$ contagem de frequência de termos nos textos que aludem à greve de abril em O Globo, a palavra "greve" tem nove registros nas primeiras páginas e nas de opinião. A expressão "vandalismo" tem duas ocorrências textuais e duas imagéticas. Além disso, em três dos nove registros do termo "violência", há uma associação com as manifestações, estabelecendo uma relação entre "greve" e "vandalismo", como nos seguintes trechos: "Protesto de centrais afeta transportes e tem violência" (manchete, 29 de abril); "(...) Mascarados fizeram atos de violência e vandalismo, com depredação de bancos e lojas. No Rio, oito ônibus foram queimados e cinco pessoas ficaram feridas (...)" (texto de primeira página, 29 de abril). A Figura 1 indica os termos mais recorrentes: 
Figura 1

Palavras frequentes nas capas e páginas de opinião de 0 Globo na greve de abril

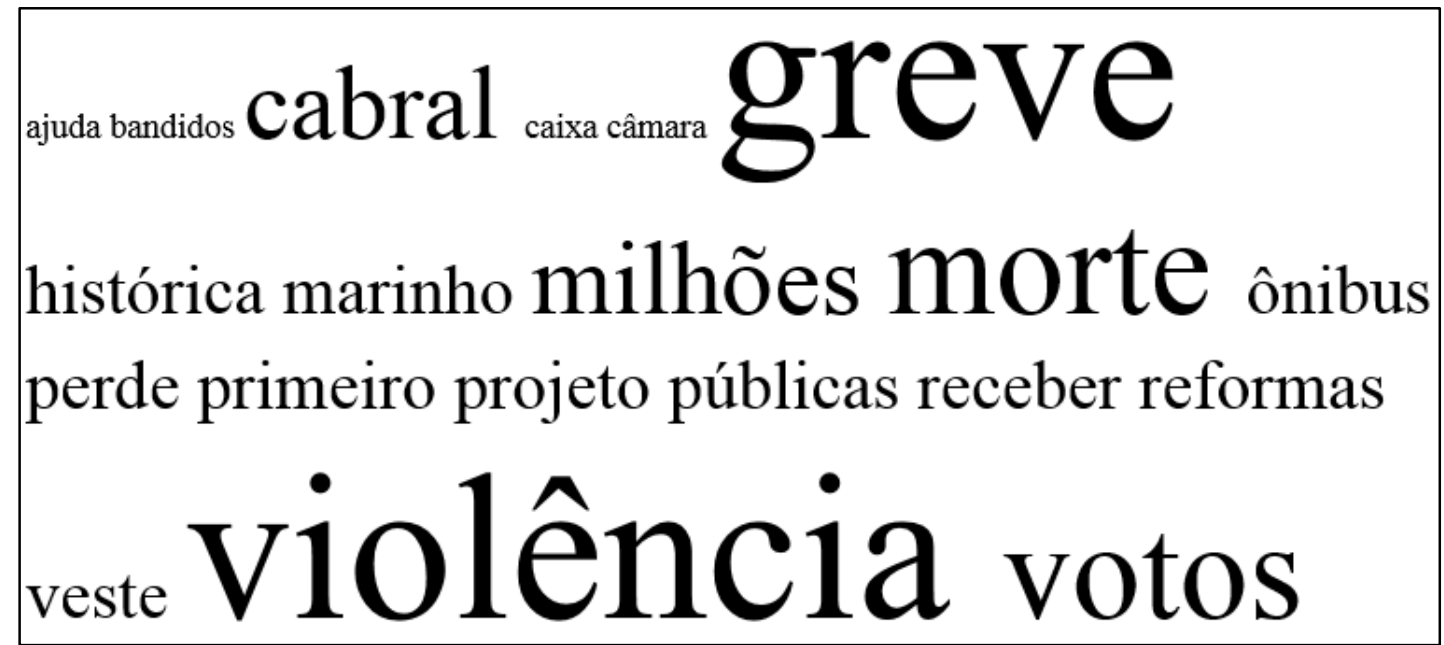

Fonte: Elaborada pelos autores com base em dados do Manchetômetro.

Na segunda greve geral do ano, $O$ Globo não fez qualquer referência em sua capa e em suas páginas de opinião às mobilizações nos três dias observados, bem como não destacou imagens da paralisação, ignorando as manifestações. Os termos "greve" ou "paralisação" desaparecem de suas páginas iniciais. Na nuvem de palavras relativas a essas páginas, a expressão mais frequente é "governo" (66 ocorrências), seguida de "política" (54) e de "Temer" (52). A Figura 2 atesta a ausência de referências textuais à greve geral nas capas e páginas de opinião nos dias analisados: 
Figura 2

Palavras frequentes nas capas e páginas de opinião de 0 Globo na greve de junho

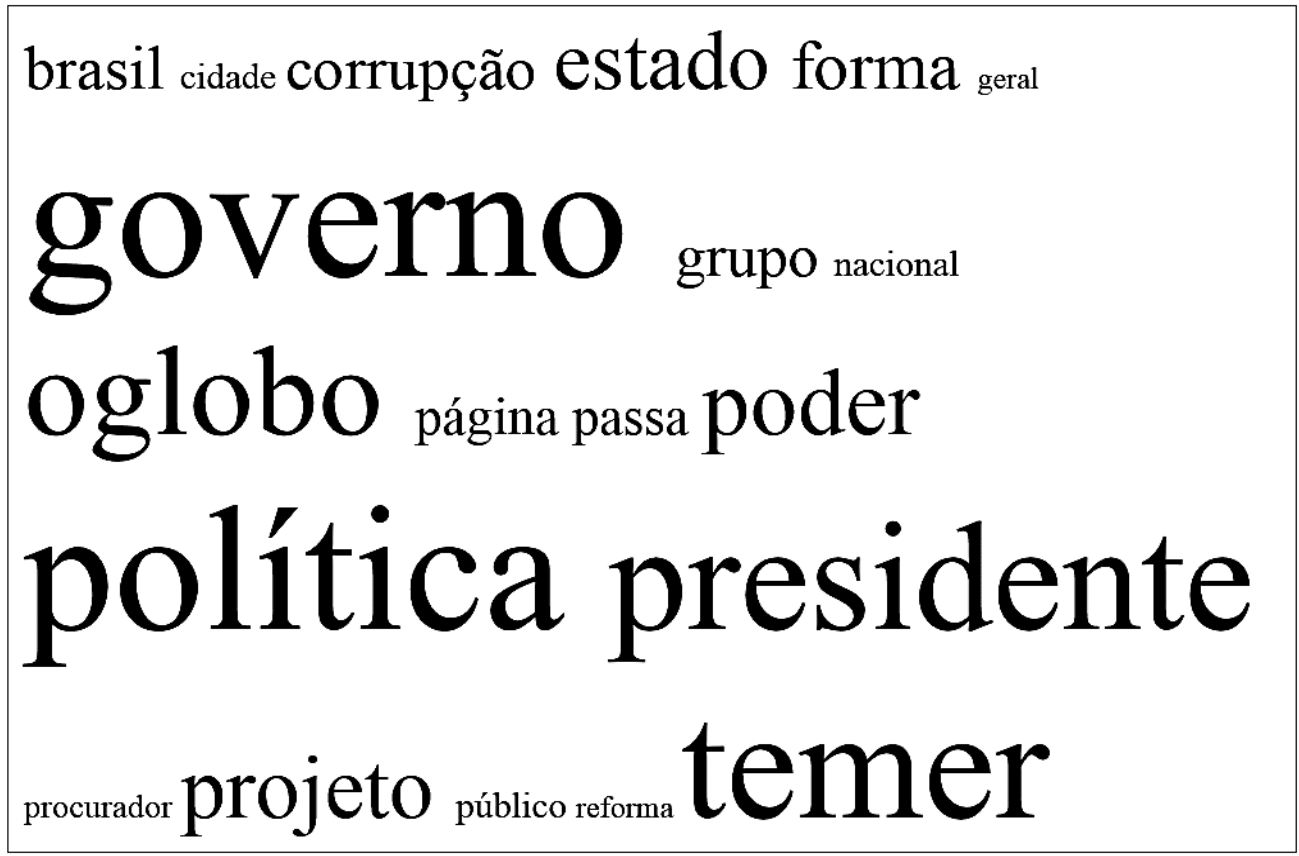

Fonte: Elaborada pelos autores com base em dados do Manchetômetro.

Nas notícias que foram veiculadas, alguns pontos são dignos de nota: no dia anterior à greve de 30 junho, um dos poucos textos sobre o tema versava acerca das precauções que as pessoas deveriam tomar para evitar transtornos no dia da paralisação. Essa espécie de manual de comportamento parece direcionado a audiências específicas, como mostra uma das recomendações apresentadas: "atenção às possibilidades de corte de ponto de empregadas domésticas". Em meio a indicações de como os consumidores podem lidar com problemas nos aeroportos, nas rodoviárias, nos bancos, nos serviços de saúde, nas escolas particulares e nos correios, o jornal destaca que, caso a profissional doméstica apresente provas para justificar sua falta, o patrão não pode penalizá-la. No entanto, a especialista consultada pelo periódico ressalta que, no caso de os transportes públicos estarem funcionando normalmente, a funcionária "não poderá culpar a paralisação". Escrita do ponto de vista dos patrões, a matéria atribui comportamento antiético às domésticas. O restante do texto explicita as condições dos "demais trabalhadores" - os que aderem coletivamente às greves, individualmente ou mesmo os que não querem participar, mas são atingidos de alguma maneira (O Globo, 2017c).

A greve do dia 28 de abril, por outro lado, foi objeto não só de textos que visavam aconselhar os leitores, como também de extenso acompanhamento nos diferentes momentos de organização e execução da mobilização. Nas cerca de 40 notícias publicadas ao longo dos três dias de nosso período de estudo, o tom da cobertura variou: ora fazendo 
descrição simples dos protestos, com menção à suposta ação agressiva de "anarquistas", ao mostrar cenários de depredação e tensão dos manifestantes com o prefeito de São Paulo, João Dória, ora abordando a intensidade das adesões à greve, denunciando a violência policial e apresentando a declaração de repúdio à atuação da Polícia Militar por parte da Ordem dos Advogados do Brasil (OAB).

Na cobertura da greve, a associação do protesto à violência não se reduziu às narrativas. Ela também esteve presente nas imagens que ilustravam as notícias, em seção de fotografias dos protestos e na divulgação de vídeos das manifestações ( $O$ Globo, $2017 b)$. Ainda que não seja incompatível com os fatos ocorridos durante a greve, essa visão dos episódios tende a reduzir a mobilização a um de seus momentos, escondendo as motivações por trás dos atos e a variedade de perfis e comportamentos dos indivíduos que a ela aderiram. Mais que isso: retira da ação dos manifestantes o sentido intrínseco de seu ato, que é o protesto contra medidas que eles defendem serem prejudiciais a grande parte da coletividade.

Além da ênfase nos transtornos e na violência, o jornal $O$ Globo também deu espaço amplo de fala aos deputados do PMDB, partido de Temer, ao próprio presidente e ao então ministro da Defesa, Raul Jungmann. O único parlamentar de oposição entrevistado foi Paulo Paim (PT-RS). No entanto, as declarações do senador expostas pelo jornal salientavam apenas a insatisfação popular com a política, algo abstrato e sem referência às reformas que estavam sendo contestadas pelas mobilizações.

Os sindicalistas e as centrais sindicais, por sua vez, como mencionado anteriormente, foram escassamente consultados pelo periódico. Embora tenham recebido alguma abertura para declarar que as greves poderiam impactar na votação das reformas, não foram discutidos os pontos que trazem potenciais prejuízos aos trabalhadores. 0 tratamento dado aos sindicalistas teve três características básicas. Primeiro, eles tiveram espaço de fala diminuto e, quando apareceram, sua opinião foi sempre marginalizada em relação à manifestação predominante de empresários e especialistas favoráveis à aprovação da reforma trabalhista no Senado. De acordo com esses especialistas, aliás, os únicos inconvenientes da reforma trabalhista são fruto de uma equivocada legislação que regula os sindicatos - dentre os seis especialistas consultados em reportagem de $O$ Globo, apenas um manifestou opinião contrária à reforma (O Globo, 2017a). Os empresários, por sua vez, associam as reformas à modernização do país e ao desenvolvimento. Segundo, eles foram caracterizados como defensores de interesses particulares e contrários à modernização do país - de acordo com o colunista Ricardo Noblat, "defendem a manutenção de vantagens de sindicatos e de segmentos da máquina do Estado que se beneficiam de ganhos na aposentadoria e nos salários" (Noblat, 2017). E, por fim, Ihes foi atribuída falta de unidade de propósito, uma vez que os sindicatos suspostamente estariam em desacordo com relação aos objetivos e diretrizes das paralisações. 


\section{O Estado de S. Paulo}

O Estadão manifestou abertamente expectativa de baixa adesão aos movimentos grevistas, além de associar o sentido da paralisação a interesses particulares dos sindicatos, classificando as mobilizações como "movimento de poucos". A capa do jornal na véspera da greve de 28 de abril traz uma chamada de capa que sugere ser a mobilização uma ampliação do feriado de segunda-feira, dia $1^{0}$ de maio, num claro esforço de desqualificar o movimento. Na mesma edição, faz um alerta aos servidores públicos federais sobre o corte de ponto no trabalho que seria empreendido pelo presidente Michel Temer (O Estado de S. Paulo, 2017a). As motivações da paralisação estão ausentes da primeira página do periódico. No dia da greve, mais uma vez temos referência negativa ao movimento, e nesse caso é a imagem principal da capa do jornal: foto de uma agência bancária recebendo tapumes para proteção de possíveis depredações, numa evidente associação da greve a atos de vandalismo. A legenda da foto traz o título "Em alerta", de intenção claramente ameaçadora.

No dia seguinte à greve geral de abril, o Estadão publicou três fotos em sua primeira página. Nenhuma delas mostra mobilizações ou atos públicos: uma estampa uma rua vazia, com lojas fechadas, explorando o sentido de esvaziamento da greve e remetendo à interpretação do movimento como ausência no trabalho, prejuízo ao comércio, "malandragem", e não como mobilização com propósito justo. As outras duas são imagens de atos de violência, uma de um incêndio e a outra de participantes da greve mascarados depredando uma agência bancária, novamente reforçando a significação do "vandalismo".

As palavras que sobressaem na narrativa da greve nas capas e páginas de opinião do Estadão entre os dias de cobertura revelam dois enquadramentos da greve: "vandalismo" e "malandragem". Esses sentidos têm alta sinergia com as imagens impressas no jornal, como mostramos anteriormente. Alguns termos, porém, mesmo quantitativamente pouco relevantes, são bastante significativos por demonstrarem um esforço redobrado do jornal e de seus colaboradores de atribuírem características negativas aos trabalhadores que aderiram à greve. Há duas referências ao termo "ergofobia" feitas na edição do jornal do dia 27 de abril, usado para fazer menção a sindicalistas envolvidos com a greve geral. A palavra, na verdade um neologismo inventado pelos colunistas do periódico, significa, em grego, pavor ou horror patológico ao trabalho, e é simplesmente uma maneira supostamente letrada de chamar os sindicalistas de vagabundos.

Em que pese a mobilização ser uma convocação de centrais sindicais, na página de opinião do dia 29 de abril há uma referência ao ex-presidente Lula como artífice da greve, chamando-o de "demiurgo petista". A palavra "demiurgo", também incomum e de origem grega, significa criador mas também "artesão do mal e do caos", e historicamente foi, inclusive, associada ao diabo. Também no Estadão aparece uma associação da greve 
à bagunça, como expresso na página de opinião do dia 28: "Greve geral ou baderna total, eis a questão". A intenção do jornal é clara e se reflete também na escolha de palavras. Nesse momento em que há uma greve geral no país, a palavra que mais aparece nas primeiras páginas e nas de opinião é "trabalho" (169 repetições) e "reforma" (76). O termo "greve" vem apenas em terceiro lugar, conforme pode ser visto na na Figura 3:

Figura 3

Palavras frequentes nas capas e páginas de opinião do Estadão na greve de abril

\section{brasil brasileira centrais estado fazer força governo greve grupos mercado parte política população presidente públicas reforma segunda sindical temer}

\section{trabalho}

Fonte: Elaborada pelos autores com base em dados do Manchetômetro.

O perfil da cobertura mudou muito durante a greve de 30 junho. O Estadão não trouxe nenhuma chamada de primeira página na véspera ou no dia da paralisação. 0 posicionamento do jornal, no entanto, permaneceu o mesmo. Alguns comentários sobre a mobilização apareceram na página de opinião do dia 29, véspera do evento, sempre negativos. A mobilização é chamada de "greve fora de hora" e acusada de falta de "bom senso e responsabilidade".

Um editorial de $1^{0}$ de julho, dia seguinte aos protestos, abre com o título: "Nem greve, nem geral" (O Estado de S. Paulo, 2017c). O parágrafo inicial do texto é digno de ser citado:

Pedir-Ihes que respeitem o direito constitucional de cada um poder ir e vir livremente é exigir demais de alguns arruaceiros travestidos de líderes sindicais e representantes dos chamados "movimentos sociais"... Resta, então, apelar para que na convocação da próxima "greve geral", em nome de um resquício de honestidade, ao menos respeitem o sentido que as palavras devem ter e façam o chamamento de mazorca, que é só o que pretendem promover (O Estado de S. Paulo, 2017c).

A avaliação que segue é categórica, as paralisações se resumem a "ações isoladas visando tão somente a impedir a livre circulação de pessoas", isto é, o já conhecido 
enquadramento da greve como distúrbio da ordem pública. Fiel a seu estilo, o Estadão mais uma vez faz uso de palavras raras para atacar as ações sindicais. Dessa vez é "mazorca", espécie de desordem ou tumulto (O Estado de S. Paulo, 2017c).

O jornal ainda produziu notícias sobre entidades sindicais que resolveram não aderir às greves, como o Sindicato dos Metroviários de São Paulo, reforçando o enquadramento de esvaziamento das mobilizações e da falta de consenso entre sindicalistas. Ao contrário da greve de abril, não há imagens relacionadas à mobilização nas capas dos três dias analisados.

As palavras mais utilizadas nos textos que fizeram referência à paralisação nas capas e páginas de opinião são "Temer" (67 ocorrências) e "trabalho" (57), seguidos de "política" (54), como pode ser verificado na Figura 4. O termo "greve" ou seus sinônimos e variações não estão entre eles.

\section{Figura 4}

Palavras frequentes nas capas e páginas de opinião do Estadão na greve de junho

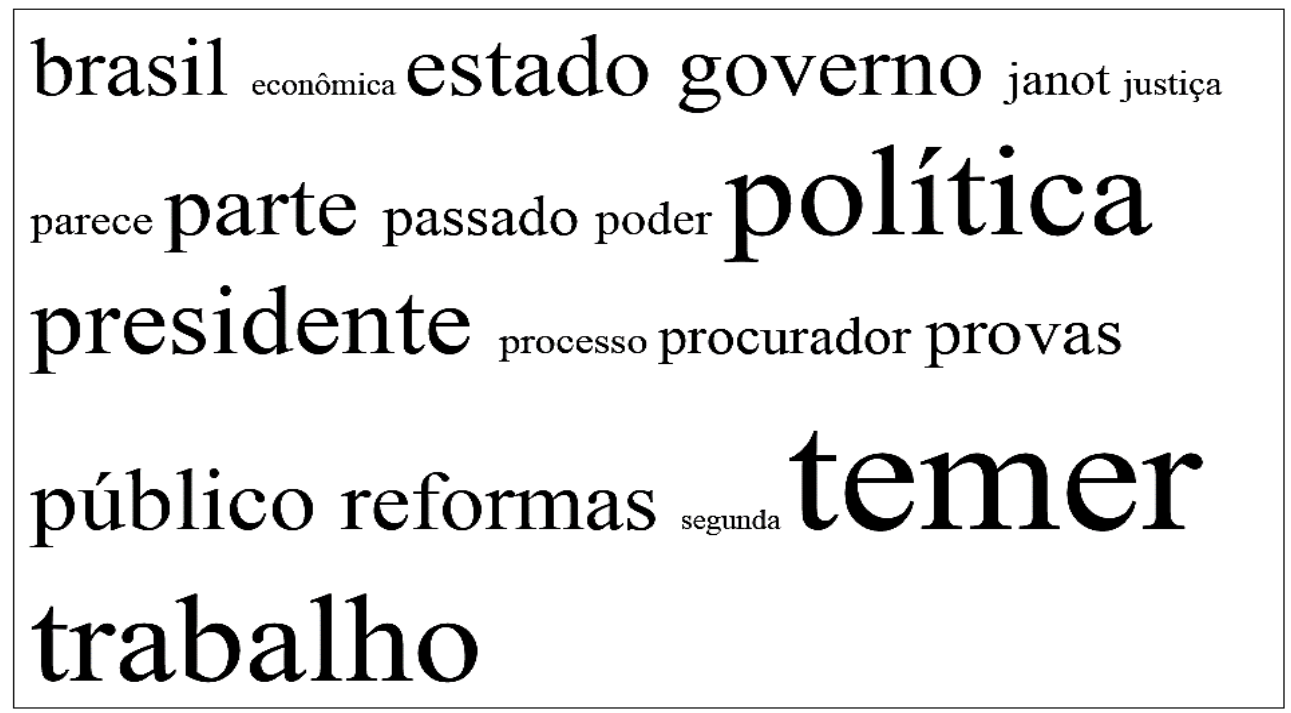

Fonte: Elaborada pelos autores com base em dados do Manchetômetro.

Além de preconizar a visão de que o movimento é de poucos, o jornal também chama os indivíduos que aderiram às greves de "baderneiros"13. Não bastasse desqualificar o direito à mobilização dos trabalhadores e difamar seus participantes, o Estadão se referiu aos movimentos sociais entre aspas, dando a entender que não se tratavam de movimentos de verdade. O periódico retira da greve o seu sentido intrínseco de direito ao protesto, ao afirmar que mudanças nas reformas em andamento devem se dar por "meios apropriados, não o que se tem visto". Ainda seguindo essa lógica, tenta criar um sentido

13 O Estado de S. Paulo. "Greve compulsória", p. A3, 29 abril 2017. 
distinto entre greve e dia de mobilizações e sugerir que o movimento tem motivação política ulterior, que é a remoção de Temer.

O jornal também tenta, com mais sutileza, resguardar retoricamente o direito à greve, definido abstratamente em bases legais, sem dizer em que medida as duas greves gerais feriram a legislação ou mesmo até que ponto a lei pode dar conta da legitimidade da luta por direitos. Segundo a visão do jornal, o direito de ir e vir é superior aos direitos de expressão e aos direitos de associação com fins políticos ou sociais, ou de reinvindicação perante as instituições de governo.

A greve é retratada como medida fracassada contra o governo Temer. O jornal se propõe a interpretar a suposta passividade de muitos ao afirmar que os "cidadãos estão cansados" e as suas manifestações são o "silêncio". Em vez de dar espaço para o debate em torno da avaliação das reformas que foram motor das manifestações, o Estadão prefere mudar de assunto e apresentar resultados de pesquisas eleitorais que aprovam personagens como Luciano Huck, Joaquim Barbosa e Sérgio Moro e reprovam outros potenciais candidatos. O senador petista Paulo Paim é novamente citado como um dos poucos a se preocupar com um novo rumo para a política.

\section{Folha de S. Paulo}

Em comparação a O Globo e Estadão, a Folha se manteve, ao menos na superfície, com discurso menos agressivo em relação aos participantes do movimento. Na véspera da primeira paralisação, dia 27 de abril, o jornal abordou o assunto na perspectiva das previsões de suspensão de serviços durante a greve, como o fechamento dos aeroportos. $\mathrm{Na}$ página de opinião desse dia, no entanto, há uma charge com sentido bastante pejorativo em relação ao movimento, como se pode observar na Imagem 1:

\section{Imagem 1}

O sentido da participação na greve de abril para a Folha

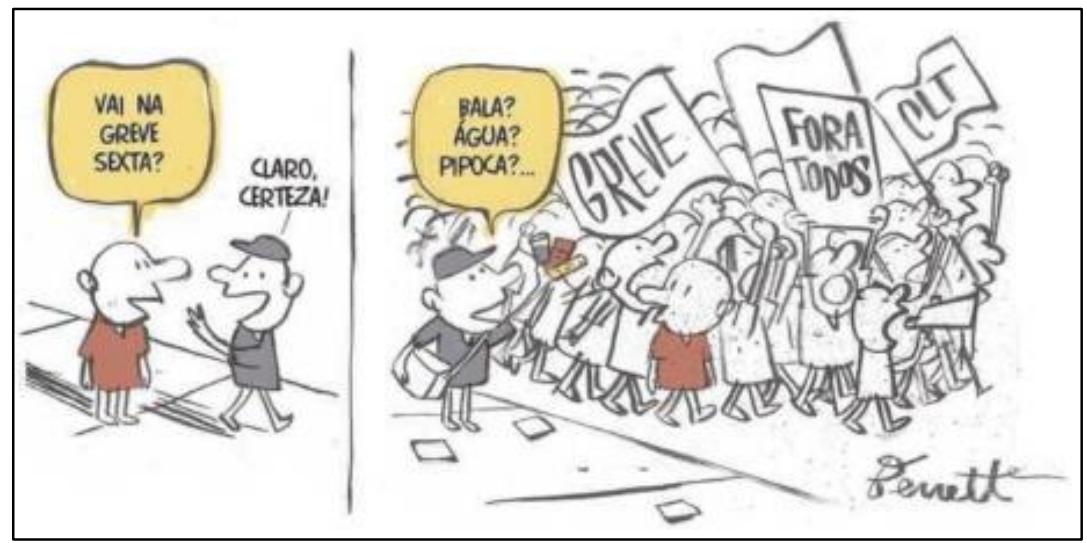

Fonte: Folha de S. Paulo, 27 de abril de 2017. 
O fato de o indivíduo vestido de cinza, supostamente um membro da classe popular, ir ao evento vender "bala, água e pipoca" mostra que o movimento está em descompasso com os anseios populares. Ademais, também sugere que aqueles que precisam trabalhar não fazem greve, interpretação que se coaduna com a associação dos grevistas à vagabundagem e à malandragem. A roupa vermelha do personagem que participa do movimento é alusão clara à CUT e ao PT. O conjunto da narrativa sugere que o movimento é feito por militantes partidarizados e não por trabalhadores.

No dia da greve geral, o jornal foi mais direto, replicando explicitamente o enquadramento esposado por seus pares, acima analisados, ao publicar uma charge com o título "Planeta dos Malandros". Aqui a referência é direta à última cena do filme O Planeta dos Macacos (Schaffner, 1968), no momento em que o protagonista, interpretado pelo ator Charlton Heston, se dá conta de que aquele planeta dominado por símios era de fato a Terra ao se deparar com a Estátua da Liberdade em ruínas, semienterrada em uma praia. Na charge, a estátua é substituída pela carteira de trabalho toda amarrotada e destruída, e um bando de pessoas desesperadas segurando cartazes com a palavra greve faz o papel do personagem de Heston. A situação retratada na charge sugere que a greve é uma luta desesperada pela manutenção de direitos trabalhistas, como se fossem um privilégio desmedido.

Em duas das três fotos publicadas no dia seguinte à paralisação de abril, o jornal explorou os mesmos sentidos adotados pelo Estadão ao expressar a associação da greve geral ao "vandalismo" e à "malandragem". A Folha foi, contudo, o único dos três veículos a apresentar uma fotografia mostrando a concentração dos grevistas. Isto é, são seis edições por jornal (três para cada evento), num total de 18, e somente uma foto na capa mostrou um aglomerado de pessoas durante ato público contra as reformas. A legenda é bastante descritiva: "Ato na noite de sexta no largo da Batata contra as reformas trabalhista e previdenciária".

A capa da Folha do dia 29 de abril de 2017 é tomada por manchete e chamadas a respeito da greve geral. A manchete da Folha, em poucas palavras, exprime pontos da narrativa negativa que permeiam as demais notícias, especialmente os enquadramentos da violência e transtorno aos cidadãos, assim como a deslegitimação das manifestações via o questionamento da adesão popular e de outros setores à greve: "Greve atinge transportes e escolas em dia de confronto" (manchete); e no sutiã ${ }^{14}$ : "Atos de rua contra reformas de Temer foram pontuais; aeroportos funcionaram normalmente". Contudo, os termos mais frequentes nos textos que fazem alusão à greve geral de abril nas primeiras páginas e nas de opinião são "projeto" (23 vezes), "poder" (16) e "reformas" (14). A palavra "greve" aparece em quarto lugar, com 13 referências, como vemos na Figura 5 :

${ }^{14}$ O termo técnico sutiã se refere à frase ou ao texto localizado abaixo de um título para completar ou amparar a informação principal. 


\section{Figura 5}

Palavras frequentes nas capas e páginas de opinião da Folha na greve de abril

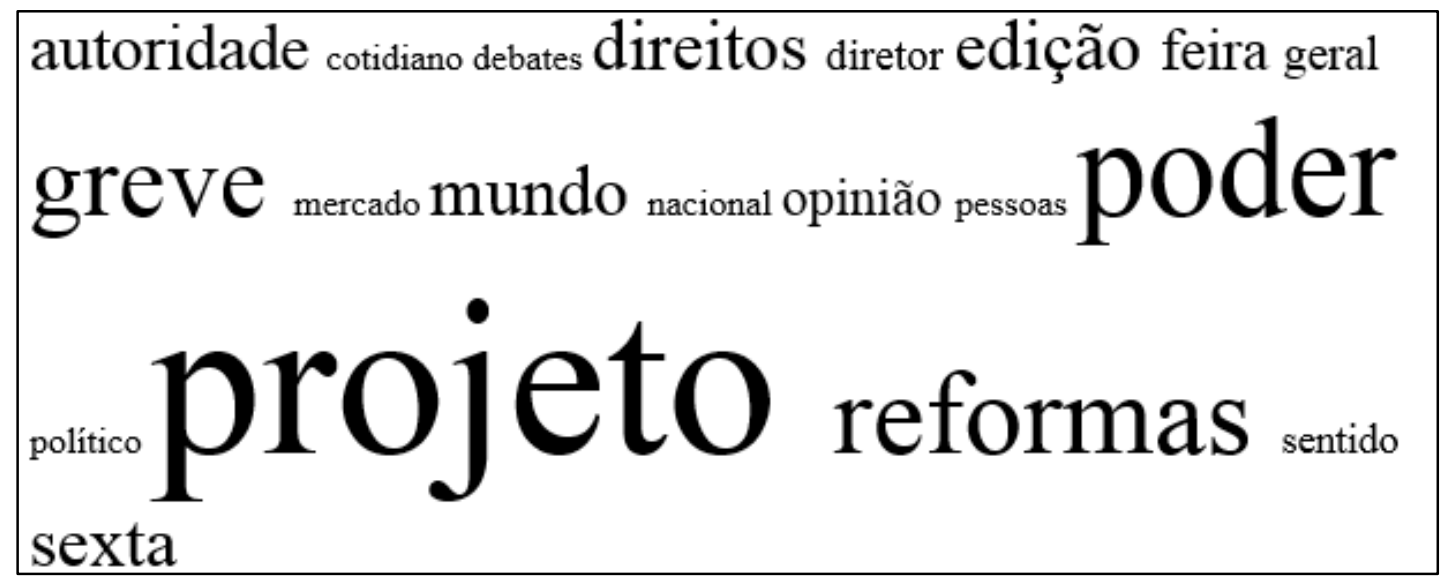

Fonte: Elaborada pelos autores com base em dados do Manchetômetro.

Nota-se na cobertura da Folha a presença de narrativas descritivas dos protestos nas principais cidades do país, mas essas descrições vêm, em sua maioria, acompanhadas de relatos de depredação e confronto, como na expressão "rastro de destruição"15 utilizada pelo jornal para caracterizar o movimento. A deslegitimação prossegue na comparação da greve a um dia com "clima de feriado" (Folha de S. Paulo, 2017b), esvaziando o propósito da ação dos indivíduos que se uniram à paralisação por aderirem à causa. Novamente notamos o silenciamento das reivindicações que sustentaram a paralisação. O jornal se resume a enunciar que os atos são "contra as reformas de Temer", deixando assim de noticiar as pautas reivindicatórias e de discutir as consequências sociais e os efeitos da aprovação dessas medidas sobre a classe trabalhadora. Assim como O Globo, a Folha também deu um enquadramento econômico negativo à greve, acusando-a de causar prejuízo às empresas e diminuir o rendimento do comércio.

Tal qual o Estadão, a Folha não deu ênfase à segunda greve do ano, no dia 30 de junho. Na véspera e no dia da paralisação não houve qualquer referência ao movimento nas primeiras páginas do jornal. Somente no dia seguinte a Folha trouxe na capa uma foto-legenda que destaca o esvaziamento da mobilização. A imagem aérea traz o texto: "SEM FORÇA Protesto na av. Paulista contra Temer e as reformas; racha entre centrais sindicais esvaziou manifestações desta sexta (30)".

O enquadramento da segunda greve seguiu o mesmo padrão. As razões se mantiveram similares, a despeito do aumento da rejeição ao presidente Temer, fomentada pelo escândalo da JBS e consequente denúncia do Ministério Público Federal (MPF). Contudo, diferentemente da notoriedade dada à greve de abril, a de junho não foi objeto

15 Relato de violência e depredação nas manifestações. Folha de S. Paulo, 29 abr. 2017. Disponível em: <http://www1.folha.uol.com.br/mercado/2017/04/1879788-protesto-contra-reforma-da-previdencia-temdepredacao-na-zona-oeste-de-sp.shtml>. Acesso em: 29 abr. 2017 
de manchetes, chamadas ou editoriais. A cobertura se limitou à publicação da foto-legenda citada acima. Essa foi a única imagem da paralisação de junho publicada na primeira página no período analisado - os demais jornais não registraram nenhuma imagem relativa ao movimento em suas capas ou páginas de opinião.

Assim como seus pares, a Folha não agendou a greve de junho. Somente no dia 10 de julho, dia seguinte ao evento, uma nota no Painel do Leitor comenta o assunto dizendo que a motivação das paralisações foi a retirada da obrigatoriedade do imposto sindical, que seria a base de sustentação econômica dos sindicatos. Explorada de maneira constante dias antes da greve de junho (Folha de S. Paulo, 2017b), a notícia de que as centrais sindicais não atuariam em conjunto nessa segunda mobilização foi usada pelo jornal como argumento para explicar a baixa adesão às mobilizações. Além de desacreditar a liderança do movimento, a Folha dá destaque à figura de Michel Temer (Seabra, 2017) ${ }^{16}$, citando-o repetidamente nas páginas de opinião das três edições à época da paralisação, e associando seu nome à palavra "poder" - ambas anotadas 27 vezes, seguidas da palavra "presidente", com 22 ocorrências. A Figura 6 revela tais preferências:

Figura 6

Palavras frequentes nas capas e páginas de opinião da Folha na greve de junho

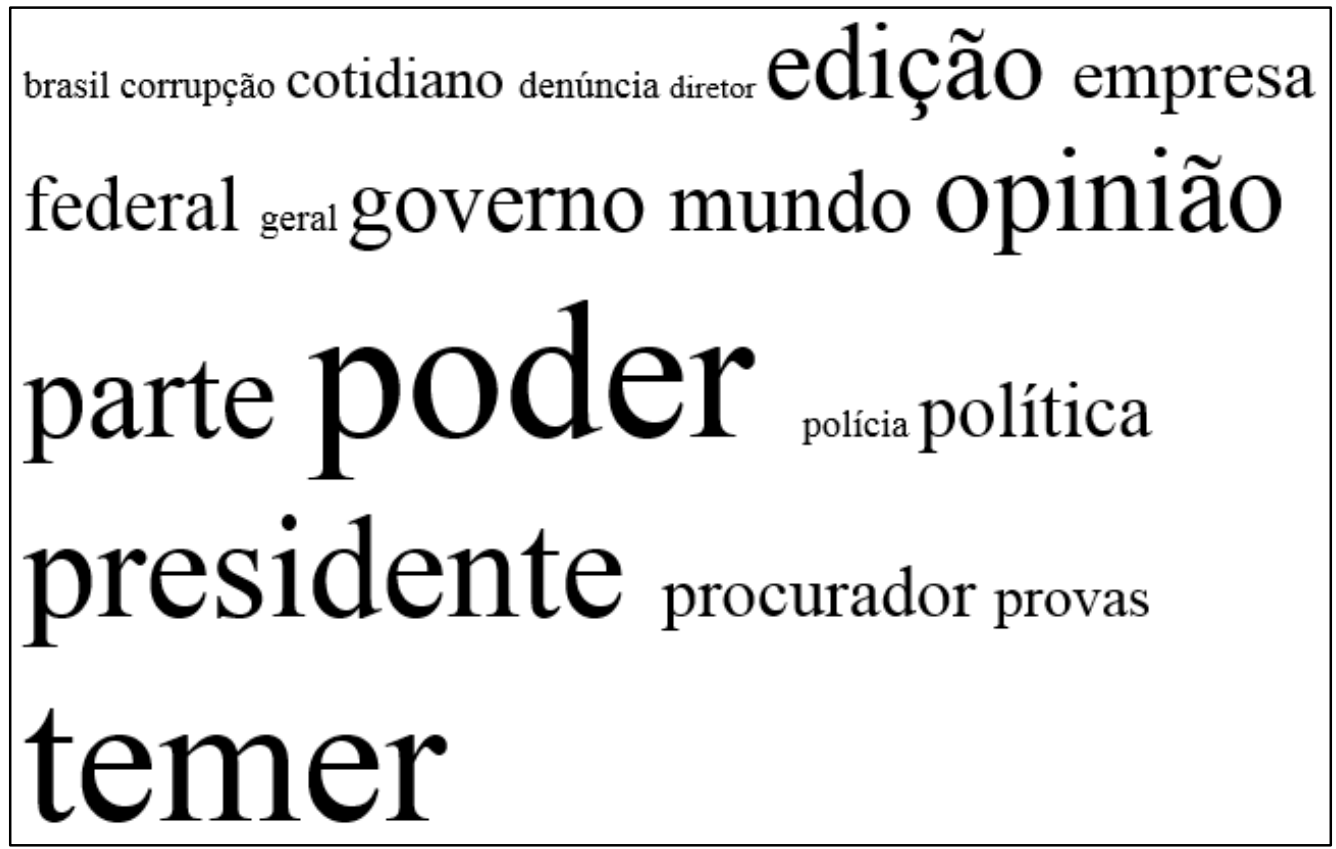

Fonte: Elaborada pelos autores com base em dados do Manchetômetro.

16 Greve esvaziada. Folha de S. Paulo, 30 jun. 2017. Disponível em: <http://m.folha.uol.com.br/mercado/2017/06/1897270-greve-no-pais-fica-esvaziada-sem-adesao-demetroviarios.shtml>. Acesso em: 30 jun. 2017. 
Segundo notícias do site da Folha, a "manifestação parcial" em todo o Brasil estaria esvaziada devido à "atuação do governo Temer". O então presidente, alvo de protestos e pedidos de impeachment nas ruas e denunciado pelo MPF, não aparece na cobertura como o objeto da indignação popular, mas como o ator político perspicaz que desmobiliza uma greve geral. Se, por um lado, o jornal agendou de modo bastante diferente cada evento, por outro, manteve constante o enquadramento da desmoralização dos movimentos.

\section{Jornal Nacional}

O meio televisivo permite ao JN associar imagens e narração simultaneamente, de maneira muito mais dinâmica do que seus pares impressos. A narrativa da violência associada às paralisações e a circunstâncias de transtorno público adquire maior dramaticidade, como, por exemplo, quando se mostram pessoas forçadas a caminhar longamente devido à paralisação do transporte público (Jornal Nacional, 2017g).

A greve de abril recebeu no $J N$ basicamente dois enquadramentos: vandalismo e transtornos ao transporte urbano e rodoviário. Bloqueios de estradas e falta de ônibus foram assuntos recorrentes em quase todas as reportagens do programa televisivo, associados à ideia de violência enquadrada como "vandalismo". O noticiário exibiu cenas com agências bancárias destruídas, pontos de ônibus depredados, veículos e pneus em chamas e até "pancadaria" no saguão do Aeroporto Santos Dumont (Jornal Nacional, 2017e), no Rio de Janeiro.

O site do $J N$ traz, além dos vídeos, as manchetes e textos transcritos das reportagens, o que nos permitiu uma aproximação metodológica à análise do discurso feita das duas greves gerais nos jornais impressos. As três palavras mais frequentes na narrativa acerca da paralisação em abril são "protestos" (26 registros), "ônibus" (23) e "manifestantes" (22). Ainda que em menor proporção, aparecem entre as expressões recorrentes os verbos "depredar" e "bloquear". A Figura 7 mostra os termos mais presentes no discurso do telejornal: 
Figura 7

Palavras frequentes no noticiário do Jornal Nacional na greve de abril bloqueadas bombas centrais cidade depredaram jOrnal periodos pessoas

Fonte: Elaborada pelos autores com base em dados do Manchetômetro.

Assim como nos jornais impressos, há um padrão na cobertura do $J N$ que busca reduzir as manifestações a atos de vandalismo. Tal enquadramento também foi usado em 29 de abril, dia seguinte à greve geral, quando o jornal noticiou os "sinais de confronto" nas cidades. Apesar de a repórter narrar que "a maior parte dos protestos foi pacífica", os 65 segundos de matéria foram dedicados a registros de depredações, incluindo as manifestações próximas à casa do então presidente Michel Temer e a cobrança dos custos dos prejuízos feita pela prefeitura de São Paulo aos sindicatos (Jornal Nacional, 2017h).

As reportagens do $J N$ sobre a greve do dia 28 de abril exploraram bastante 0 recurso das entrevistas de pessoas supostamente envolvidas ou atingidas pelo movimento. O jornal usou as reportagens para fazer repetidos contrapontos à paralisação, por exemplo, dando voz a trabalhadores que se sentiram prejudicados com as interdições e interrupções de serviços. Durante a cobertura dos atos no Rio de Janeiro, o telejornal da Rede Globo exibiu a fala de uma mulher transtornada ao relatar que a suspensão da circulação dos transportes limitava o seu direito de ir e vir (Jornal Nacional, 2017e).

É importante salientar, entretanto, que a cobertura do $J N$ deu espaço de fala direta aos diferentes lados envolvidos na greve, sejam trabalhadores que aderiram ao movimento ou aqueles que lhe foram críticos, e relatou casos de agressão policial (Jornal Nacional, 2017g). Entretanto, não houve equilíbrio na apresentação dos diferentes pontos de vista. O presidente da Força Sindical, Paulo Ferreira da Silva, apoiador do impeachment e 
adversário público da CUT e do PT, falou por 57 segundos e destacou o sucesso da adesão de trabalhadores às paralisações (Jornal Nacional, 2017a). O governo federal foi representado pelo ministro da Justiça, Osmar Serraglio, que teve 98 segundos de fala (Jornal Nacional, 2017f), ou seja, quase o dobro da fala de Paulinho da Força. O ministro declarou que o direito à greve é democrático e legítimo, mas não poderia aceitar que pessoas que não queriam participar fossem afetadas com interdições. Com parcos 13 segundos de fala, o presidente da CUT-RJ, Marcelo Rodrigues, afirmou que as interdições de rodovias e paralisações dos transportes são necessárias para que o protesto tenha impacto (Jornal Nacional, 2017e).

$\mathrm{O}$ argumento econômico também foi utilizado pelo $J N$ para desqualificar a greve. Em entrevista, uma comerciante afirma estar desesperada pelo desempenho das vendas no dia da paralisação. O telejornal estimou em $70 \%$ a queda no movimento (Jornal Nacional, 2017d), expondo maior preocupação com o impacto nos índices da economia do que com o resultado das reformas sobre a vida dos brasileiros e o seu direito de lutar politicamente contra elas.

Por fim, o programa ainda associou a greve a um feriado (Jornal Nacional, 2017c), em um evidente esforço de desvalorização da luta dos trabalhadores por seus direitos. 0 desequilíbrio da cobertura se mostra na reduzida exposição recebida pelas pautas que paralisaram o país. Praticamente não houve espaço dentro dos 1.242 segundos de cobertura da primeira greve pelo $J N$ para esclarecer os pontos de reivindicação dos movimentos sociais. O noticiário se limitou a dizer que a greve tem como objetivo protestar contra as reformas. Por outro lado, o jornal gastou 121 segundos explicando as mudanças decorrentes das reformas propostas por Temer (Jornal Nacional, 2017b), durante os quais foi dada voz ao governo para justificar a aprovação dos projetos com base no suposto "rombo na Previdência Social" de $\mathrm{R} \$ 188,8$ bilhões, que deixaria o Tesouro Público sem recursos para as futuras aposentadorias. O espaço para o contraditório, dividido em três momentos da matéria, ocupou 30 segundos e continha a reivindicação das centrais sindicais pela destinação total dos recursos para a previdência. No entanto, a reportagem volta a dar voz para o governo responder que tal medida impossibilitaria a manutenção de investimentos em outras áreas, como saúde e educação, ou seja, Ihe confere a última palavra.

Na segunda greve geral, no dia 30 de junho, o JN apresentou uma cobertura sete vezes mais breve que a de abril. Foram 176 segundos (Jornal Nacional, 2017i) dedicados ao que o telejornal nomeou de "tentativa de greve geral" contra as reformas e Temer. A maior parte da reportagem apresenta um panorama dos atos de protesto nas principais cidades do país, sejam os qualificados como pacíficos, sejam os que foram enquadrados como violentos - como furar e queimar pneus de ônibus. Nos dez segundos de fechamento da notícia foram relatadas ações de depredação no Rio de Janeiro e em São Paulo, além de confronto com a polícia. Não houve cobertura nos dias que antecederam as duas greves e apenas a primeira contou com notícias no dia seguinte (29 de abril). Repetindo o 
comportamento relativo à primeira greve, o noticiário silenciou a respeito das pautas defendidas pelos manifestantes.

Assim como seus pares impressos, o JN na cobertura da greve geral privilegiou os enquadramentos do vandalismo e da dificuldade de locomoção. As três palavras mais frequentes na narrativa do telejornal acerca da paralisação em junho foram "ônibus" (9 registros), "manifestantes" (7) e "metrô" (4). Outras expressões relacionadas a deslocamento, como "aeroporto", "avenida" e "bloqueio", aparecem em menor proporção, como revela a Figura 8:

Figura 8

Palavras frequentes no Jornal Nacional na greve de junho

acesso aeroporto apesar avenida balas bloquearam borracha brasil dispersou federal fizeram garagens geral greve internacional

\section{manifestantes metrô

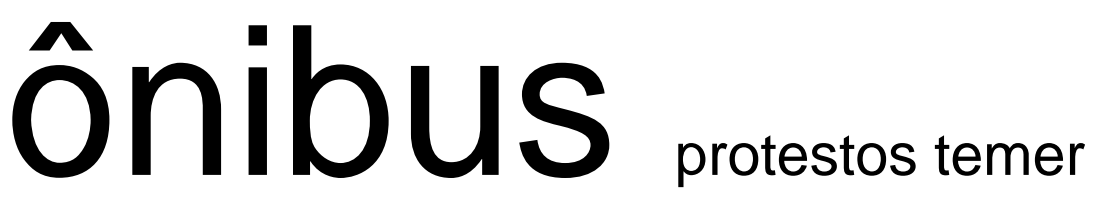

Fonte: Elaborada pelos autores com base em dados do Manchetômetro.

As manchetes do site do $J N$ confirmam a análise da cobertura em si, que reduz as greves aos enquadramentos do vandalismo e da dificuldade de locomoção. O movimento foi apresentado como um abuso praticado por grupos contra o interesse público, particularmente no que toca à livre locomoção pelo espaço urbano. A cobertura se concentrou em informar onde existiam bloqueios e onde era possível transitar, destacando os pontos de tensão entre grevistas - apresentados recorrentemente como vândalos - e policiais.

\section{Avaliação geral dos resultados}

O presente artigo não confirma a tese de Shahin et al. sobre o comportamento dos grandes jornais brasileiros, enunciada a partir do estudo do caso das manifestações de junho de 2013, segundo a qual estes praticariam um paradigma de protesto moderado (Shahin et al., 2016). Pelo contrário, o que vimos aqui em relação às greves de 2017 foi um paradigma de protesto "de livro-texto", isto é, claro, intenso e incontroverso. A grande imprensa brasileira foi muito além do ato de declarar-se favorável às reformas de Temer, 
ela fez uso de estratégias de representação que têm a função clara de desqualificar e desacreditar os movimentos sociais. Esse padrão de comportamento da mídia pode ser evidenciado a partir de cinco enquadramentos mais evidentes utilizados na representação discursiva das greves gerais de 2017: (1) violência e vandalismo, (2) malandragem, ação egoísta e desorganizada, (3) transtorno do espaço público, (4) fonte de prejuízo à economia e (5) ausência de legitimidade popular.

Embora cada enquadramento seja usado muitas vezes de maneira isolada, há uma sinergia entre eles no sentido de deslegitimar as manifestações. O primeiro enquadramento, certamente foi o mais frequente e dramático, dominando não somente as imagens associadas aos eventos, mas também as palavras mais recorrentes no noticiário, como mostraram as nuvens. Identificamos exemplos típicos de sua utilização, por exemplo, pelo jornal $O$ Globo na fotografia de capa de um ônibus em chamas, relatando atos de vandalismo; pelo Estadão ao ilustrar a primeira página com agências bancárias instalando tapumes; pelo uso de expressões como "rastros de destruição" pela Folha; e pela impactante sequência de planos feita pelo JN de pneus queimando, pontos de ônibus quebrados e até uma briga no aeroporto do Rio de Janeiro. Em si, noticiar tais ocorridos não seria sinal de viés midiático se os meios de comunicação tivessem dado espaço para seu contraponto: ajuntamentos pacíficos de manifestantes. O significado também poderia ser outro se o foco na violência não viesse acompanhado de outros elementos do paradigma de protesto, como o silenciamento discursivo das pautas dos manifestantes e a ausência nos textos de opinião de perspectivas críticas acerca das reformas que eram o objeto das manifestações. A redução das mobilizações populares à violência e ao distúrbio da paz urbana lança sobre os manifestantes um manto de irracionalidade, de ameaça, de intratabilidade que tem o potencial de lhes roubar a legitimidade do movimento aos olhos daqueles que dele não fazem parte.

O enquadramento da "malandragem, ação egoísta e desorganizada" apresenta à opinião pública uma liderança de greve em busca de seus próprios interesses, destaque para as diversas referências ao receio dos sindicatos em relação ao fim da contribuição obrigatória. Mais uma vez temos uma estratégia reducionista de roubar legitimidade dos movimentos, ao reduzi-los a instrumentos de lideranças sindicais para garantir a estas a manutenção de privilégios, como se não estivessem em pauta nas reformas direitos fundamentais de toda a classe trabalhadora.

As notícias anteriores à segunda greve, de um possível racha entre os movimentos no comando da mobilização, tentam mostrar um suposto rompimento da liderança sindical, que seria produto do conflito de interesses mesquinhos e particulares, mais uma vez afastando-a do interesse coletivo ou público. A esse cenário soma-se o relato da greve como um ambiente de feriado, em especial porque a primeira data coincidia com um feriado nacional (10 de maio). Essa associação reincidente promove ao menos duas concepções negativas da greve: o "clima de feriado" sugere desmobilização, portanto, fracasso da greve e, ao mesmo tempo, um ardil malandro para não trabalhar. O Estadão 
chega a imputar a palavra "ergofobia" aos grevistas para desqualificá-los (Estado de $S$. Paulo, 2017b). Essa compreensão da greve como uma atitude de malandragem aparece de maneira explícita na opinião de um "especialista" publicada em O Globo, segundo o qual não deve ser permitido que as empregadas domésticas justifiquem sua ausência no trabalho caso haja transporte público para sua locomoção.

Um clássico do paradigma de protesto, o transtorno à ordem pública, também foi enfatizado na cobertura das greves de 2017. Adepto do emprego de terminologia dramática, o Estadão nomeou a situação de "mazorca", ou seja, rebelião e desordem. Tal elemento geralmente vem associado ao enquadramento da violência e contribui para emprestar às greves uma imagem de irracionalidade.

Declarados adeptos da disciplina fiscal e do livre mercado em detrimento de políticas sociais típicas de um Estado de bem-estar social, a grande mídia brasileira tentou na cobertura das paralisações fazer algo quase impossível, que é rejeitar os propósitos das greves sem ao menos debatê-los, enquadrando o movimento como atraso. Segundo editorial do jornal O Globo, "A 'greve geral' das corporações" (Noblat, 2017), além de ser um entrave para a economia retomar o crescimento, a mobilização também foi noticiada como causadora de prejuízos, visto o baixo rendimento do comércio durante os dias de paralisação. O JN, em entrevista com comerciantes, estima que os prejuízos causados pelo baixo consumo chegariam a um percentual de 70\% (Jornal Nacional, 2017d). É interessante ressaltar que, se por um lado a mídia demonstra preocupação com os impactos negativos causados por dois dias de paralisação, por outro faz vista grossa ao impacto que as reformas da previdência e trabalhista teriam para a vida de milhões de trabalhadores brasileiros.

O quinto enquadramento é um ataque frontal ao movimento, pois the atribui ausência de legitimidade popular. O Estadão publicou na capa foto de rua esvaziada e comércio fechado, vinculando a ausência de movimento à malandragem e repetindo o bordão "nem greve, nem geral". O único contraponto a esse padrão foi uma capa da Folha com uma foto mostrando uma grande concentração de grevistas em ato público durante a primeira greve. Utilizando-se da entrevista de populares, o JN apresentou falas de trabalhadores que se diziam prejudicados pela ausência de transporte público, e nomeou o evento de "tentativa de greve" (Jornal Nacional, 2017e).

Ainda que não seja objetivo deste artigo, tão importante quanto analisar os enquadramentos narrativos da cobertura midiática é identificar no agendamento das notícias elementos silenciados, ausentes do texto jornalístico. Os sindicatos organizadores do movimento marcaram presença nas manchetes, chamadas e editoriais dos jornais mormente como alvos de críticas e raramente como agentes dotados de voz e argumentos. Sua participação, se comparada ao destaque dado às posições do governo Temer, foi claramente marginalizada, para tomar emprestado um termo corrente na literatura sobre o paradigma de protesto. Apresentados como autointeressados, desunidos e promotores de transtornos, os sindicatos receberam caracterização pejorativa durante toda a 
cobertura, enquadramento inexistente em relação ao governo, mesmo quando este, como no caso da segunda greve, estava sendo alvo de denúncias seríssimas de corrupção que envolviam diretamente o presidente da República e muitos de seus principais aliados. Pelo contrário, Temer é até apresentado como hábil desarticulador do movimento da segunda greve pela Folha. A oportunidade de fala concedida aos líderes grevistas se limitou a poucos segundos no JN. Nos demais veículos não houve espaço algum para a exposição das pautas reivindicatórias.

Outros movimentos sociais participantes das greves, como o de mulheres, semteto e camponeses, foram ignorados pela grande mídia, que só deu voz, ainda que parca, às grandes centrais sindicais e aos grandes coletivos de movimentos como o Povo Sem Medo e a Frente Brasil Popular. Em resumo, seja por meio de enquadramento ou de agendamento, a grande mídia brasileira tratou os protestos populares contra as reformas de Temer seguindo à risca o que a literatura conceitua como paradigma de protesto.

\section{Considerações finais}

É importante notar que o caso estudado se aproxima mais do de Hong Kong, com meios de comunicação conservadores tentando deslegitimar movimentos progressistas, do que do caso dos EUA, onde uma mídia que defende uma ética profissional que supostamente estaria acima da politização utiliza o paradigma de protesto também contra movimentos progressistas, em defesa do status quo. Isso porque a grande mídia brasileira é politizada a ponto de sacrificar qualquer defesa séria de critérios profissionais de equilíbrio e pluralidade de ideias. Em outras palavras, não se trata de uma mídia como a norte-americana.

Em segundo lugar, mesmo que assumíssemos, ainda que falsamente, que a mídia brasileira apresenta padrões de profissionalismo e pluralismo similares à estadunidense, a interpretação norte-americana também não se aplicaria porque no nosso caso quem defende o status quo são os manifestantes, enquanto a mídia e o governo querem alterálo por meio de reformas neoliberais. Certamente, os critérios de determinação do que seria o status quo em relação a um dado contexto político e social precisam ser mais bem compreendidos para que um modelo de explicação que use essa variável seja viável.

Os estudos que observaram variabilidade na adoção do paradigma de protesto por parte da grande mídia em outros países que não Estados Unidos, Brasil ou China não são de muita ajuda aqui, pois, como dissemos, no caso brasileiro em pauta ele se mostrou bastante claro e consistente. Como a quase totalidade da grande mídia do Brasil está concentrada em uma faixa estreita do espectro ideológico que vai da centro-direita à direita, não há maneiras confiáveis de controlar a ideologia no emprego do paradigma.

Por fim, ainda que o modelo do paradigma moderado de protesto proposto por Shahin et al. (2016) para o caso brasileiro não possa ser estendido para o estudo das greves de 2017, a tese da proximidade ideológica entre mídia e governo como causa eficaz 
para a ocorrência do paradigma de protesto parece promissora, a despeito de os autores cometerem o absurdo de postular afinidade ideológica entre a Folha e o Partido dos Trabalhadores (PT). Certamente o caso das manifestações de junho de 2013, devido às mudanças de posicionamento da mídia no decorrer dos eventos, poderia ser usado para testar de maneira consistente a viabilidade dessa hipótese para a ocorrência do paradigma de protesto. Deixaremos tal matéria para uma oportunidade futura.

\section{Referências bibliográficas}

AlbuQUerque, A. "A campanha presidencial no Jornal Nacional: observações preliminares". Comunicação \& Política, vol. 1, nº 1, p. 23-40, 1994.

AldÉ, A.; Mendes, G.; Figueiredo, M. "Tomando partido: imprensa e eleições presidenciais em 2006". Política e Sociedade, no 10, p. 153-172, 2007.

AMB, A. D. M. B. "Manifesto - Movimento de mulheres contra a reforma da previdência social convocam lutas para o mês de março de 2017", 2017. Disponível em:

<http://www.marchamundialdasmulheres.org.br/wp-

content/uploads/2017/02/manifestoMulheres2b-1.pdf>. Acesso em: 10 jun. 2017.

ASHLEY, L.; OLSON, B. "Constructing reality: print media's framing of the women's movement, 1966 to 1986". Journalism \& Mass Communication Quarterly, vol. 75, no 2, p. 263-277, 1998.

Avritzer, L.; Milani, C.; Braga, M. A ciência política no Brasil: 1960-2015. Rio de Janeiro: FGV, 2016.

AyouB, A. H. "Mídia e movimentos sociais: a satanização do MST na Folha de S. Paulo". Estudos em Jornalismo e Mídia, vol. 4, no 1, p. 79-93, 2007.

AzeVEdo, F. A. A grande imprensa e o PT (1989-2014). São Carlos: Editora UFSCar, 2017.

BENFORD, R. D.; SNOW, D. A. "Framing processes and social movements: an overview and assessment". Annual Review of Sociology, vol. 26, p. 611-639, 2000.

BEZERRA, H. D.; Mundim, P. S. "Qual foi o papel das variáveis midiáticas na eleição presidencial de 2010?". Opinião Pública, vol. 17, no 2, p. 452-476, 2011.

BOAS, T. C. "Television and neopopulism in Latin America: media effects in Brazil and Peru". Latin American Research Review, vol. 40, nº 2, p. 27-49, 2005.

BoIto JR., A.; MARCELINO, P. "O sindicalismo deixou a crise para trás? Um novo ciclo de greves na década de 2000". Caderno CRH, vol. 23, no 59, p. 323-338, 2010.

BoYLE, M. P.; ARMSTRONG, C. L. "Measuring level of deviance: considering the distinct influence of goals and tactics on news treatment of abortion protests". Atlantic Journal of Communication, vol. 17, n० 4, p. 166-183, 2009.

BOYLE, M. P., et al. "The influence of level of deviance and protest type on coverage of social protest in Wisconsin from 1960 to 1999". Mass Communication and Society, vol. 7, no 1, p. 43-60, 2004.

. "Newspapers and protest: an examination of protest coverage from 1960 to $1999 "$.

Journalism \& Mass Communication Quarterly, vol. 82, no 3, p. 638-653, 2005. 
BRINGEL, B. "Ativismo transnacional, o estudo dos movimentos sociais e as novas geografias póscoloniais". Estudos de Sociologia, vol. 2, no 16, p. 185-215, 2014.

CAMPOS, L. A. "A identificação de enquadramentos através da análise de correspondências: um modelo analítico aplicado à controvérsia das ações afirmativas raciais na imprensa". Opinião Pública, vol. 20, no 3, p. 377-406, 2014.

CARDoso, A.; Gindin, J. "O movimento sindical na Argentina e no Brasil (2002-2014)". Sociedade e Estado, vol. 32, no 1, p. 13-37, 2017.

ChAN, J. M.; LeE, C.-C. Journalistic "paradigms" of civil protests: a case study of Hong Kong. In: ARNo, A.; DisSANAYAKE, W. (eds.). The news media in national and international conflict. Boulder, CO: Westview, p. 183-202, 1984.

CRUZ, F. S. "Os movimentos sociais e a mídia em tempos de globalização: um estudo das abordagens de jornais brasileiros e espanhóis sobre o MST e os direitos humanos". Revista Famecos: Mídia, Cultura e Tecnologia, vol. 19, no 3, p. 795-820, 2012.

Comparato, B. K. "A ação política do MST". São Paulo em Perspectiva, vol. 15, no 4, p. 105-118, 2001.

CORBIN, J.; STRAUSS, A. "Grounded theory research: procedures, canons, and evaluative criteria". Qualitative Sociology, vol. 13, no 1, p. 3-21, 1990.

DARDIS, F. E. "Marginalization devices in U.S. press coverage of Iraq War protest: a content analysis". Mass Communication and Society, vol. 9, n² 2, p. 117-135, 2006.

DETENBER, B. H., et al. "Frame intensity effects of television news stories about a high-visibility protest issue". Mass Communication and Society, vol. 10, no 4, p. 439-460, 2007.

ENTMAN, R. M. "Framing: toward clarification of a fractured paradigm". Journal of Communication, vol. 43, no 4 , p. 51-58, 1993.

FERES JúnIOR, J.; SASSARA, L. D. O. "Corrupção, escândalos e a cobertura midiática da política". Novos Estudos - Cebrap, vol. 35, no 2, p. 205-225, 2016.

FOLHA DE S. PAULO. "A greve e as reformas", p. A2, 29 abr. 2017a, 32168. Disponível em: <http://www1.folha.uol.com.br/opiniao/2017/04/1879714-a-greve-e-as-reformas.shtml>. Acesso em: nov. 2019.

. "Centrais sindicais divergem sobre alternativas ao imposto sindical". São Paulo, 30 jun. 2017b. Disponível em: <http://www1.folha.uol.com.br/mercado/2017/06/1897534-centraissindicais-divergem-sobre-alternativas-ao-imposto-sindical.shtml>. Acesso em: 15 ago. 2017.

GAMSON, W. A.; WolfSFelD, G. "Movements and media as interacting systems". The Annals of the American Academy of Political and Social Science, vol. 528, p. 114-125, 1993.

GITLIN, T. The whole world is watching: mass media in the making \& unmaking of the new left. Berkeley, CA: University of California Press, 1981.

GLASER, B. G.; STRAUSS, A. L. The discovery of grounded theory: strategies for qualitative research. Chicago: Aldine Pub. Co., 1967.

GofFMAN, E. Frame analysis: an essay on the organization of experience. London: Penguin Books, 1974. 
GoHN, M. D. G. "A produção sobre movimentos sociais no Brasil no contexto da América Latina/The production on social movements in Brazil in The Latin America context". Política \& Sociedade, vol. 13, no 28, 2014.

HARLOW, S.; JOHNSON, T. J. "Overthrowing the protest paradigm? How the New York Times, Global Voices and Twitter covered the Egyptian Revolution". International Journal of Communication, vol. 5, 2011.

HARLOW, S., et al. "Protest paradigm in multimedia: social media sharing of coverage about the crime of Ayotzinapa, Mexico". Journal of Communication, vol. 67, no 3, p. 328-349, 2017.

IYENGAR, S.; KINDER, D. R. News that matters: television and American opinion. Chicago: University of Chicago Press, 1987.

JORNAL NACIONAL. "Centrais sindicais e CUT consideram paralisação 'muito bem-sucedida'", 28 abr. 2017a. Disponível em: <https://globoplay.globo.com/v/5834595/programa/>. Acesso em: 24 ago. 2017.

. "Conheça as principais mudanças propostas pela reformas", 28. abr. 2017b. Disponível em: <https://globoplay.globo.com/v/5834632/programa/>. Acesso em: 28 ago. 2017.

. "No Recife, 1,8 milhão de passageiros ficam sem transporte público", 28 abr. 2017c. Disponível em: <https://globoplay.globo.com/v/5834597/programa/>. Acesso em: 16 ago. 2017.

. "Principais cidades do Sul ficam sem transporte coletivo", 28 abr. 2017d. Disponível em: <https://globoplay.globo.com/v/5834593/programa/>. Acesso em: 12 ago. 2017.

. "Protestos no Rio têm confrontos e oito ônibus queimados", 28 abr. 2017e. Disponível em: <https://globoplay.globo.com/v/5834588/programa/>. Acesso em: 20 jul. 2017.

. "Serraglio diz que não aceita 'dificuldades criadas' a quem não fez greve", 28 abr. 2017f. Disponível em: <https://globoplay.globo.com/v/5834621/programa/>. Acesso em: 27 ago. 2017.

. "Estudante agredido por policial em protesto em Goiânia está em estado grave", 29 abr. 2017g. Disponível em: <https://globoplay.globo.com/v/5836431/programa/>. Acesso em: 21 ago. 2017.

. "Prefeitura de São Paulo diz que vai mandar conta de prejuízos para sindicatos", 29 abr. 2017h. Disponível em: <https://globoplay.globo.com/v/5836418/programa/>. Acesso em: 16 ago. 2017.

. "Sindicatos e movimentos sociais fazem protestos contra Temer", 30 jun. $2017 \mathrm{i}$.

Disponível em: <https://globoplay.globo.com/v/5978054/>. Acesso em: 26 ago. 2017.

KUCINSKI, B. A síndrome da antena parabólica: ética no jornalismo brasileiro. São Paulo: Editora Fundação Perseu Abramo, 1998.

KYRIAKIDOU, M.; Olivas Osuna, J. J. "The indignados protests in the Spanish and Greek press: moving beyond the 'protest paradigm'?". European Journal of Communication, vol. 32, no 5, p. 457$472,2017$.

LEE, F. L. "Triggering the protest paradigm: examining factors affecting news coverage of protests". International Journal of Communication, vol. 8, p. 2.725-2.746, 2014.

LIMA, V. Mídia: teoria e política. São Paulo: Editora da Fundação Perseu Abramo, 2001. 
LIPSKY, M. "Protest as a political resource". The American Political Science Review, vol. 62, no 4, p. $1.144-1.158,1968$.

Matos, C. Journalism and political democracy in Brazil. Lanham, MD: Lexington Books, 2008.

MCLEOD, D. M. "Communicating deviance: the effects of television news coverage of social protest". Journal of Broadcasting \& Electronic Media, vol. 39, no 1, p. 4-19, 1995.

. "News coverage and social protest: how the media's protest paradigm exacerbates social conflict". Journal of Dispute Resolution, n 1, p. 1-10, 2007.

MCLeOd, D. M.; Detenber, B. H. "Framing effects of television news coverage of social protest". Journal of Communication, vol. 49, no 3, p. 3-23, 1999.

MCLEOD, D. M.; HERTOG, J. K. Social control and the mass media's role in the regulation of protest groups: the communicative acts perspective. In: KASISOMAYAJULA, D. D. V. (ed.). Mass media, social control and social change. Ames, IO: Wiley-Blackwell, p. 314-15, 1999.

MENDONÇA, R. F.; SimÕES, P. G. "Enquadramento: diferentes operacionalizações analíticas de um conceito". Revista Brasileira de Ciências Sociais, vol. 27, no 79, p. 187-201, 2012.

Meneses, S. "Fora Collor' e Marchas de Junho: imprensa e construção de sentidos sobre as mobilizações populares de 1992 e 2013". Resgate, vol. XXII, no 28, p. 13-22, jul.-dez. 2014.

Miguel, L. F. "Mídia e eleições: a campanha de 1998 na Rede Globo". Dados, vol. 42, no 2, p. 253$276,1999$.

. Política e mídia no Brasil: episódios da história recente. Brasília, DF: Editora Plano, 2002.

. A descoberta da política - a campanha de 2002 na Rede Globo. In: RuBim, A. A. (org.). Eleições presidenciais em 2002: ensaios sobre mídia, cultura e política. São Paulo: Hacker Editores, p. 95-105, 2004.

Miguel, L. F.; Biroli, F. "Meios de comunicação de massa e eleições no Brasil: da influência simples à interação complexa". Revista USP, vol. 90, p. 74-83, 2011.

MoABIs, M. "A cobertura dos protestos de junho de 2013 nos jornais Diário dos Campos e Jornal da Manhã". Revista Brasileira de Ensino de Jornalismo, vol. 4, no 25, p. 3-15, jan.-jun. 2014.

Mor, C. "Planeta dos Malandros". Folha de S. Paulo, São Paulo, ano 97, no 32167, p. A2, 28 abril 2017.

MourÃo, M. "Vozes silenciadas. A cobertura da mídia sobre o Movimento dos Trabalhadores Rurais Sem Terra durante a Comissão Parlamentar Mista de Inquérito". Intervozes - Coletivo Brasil de Comunicação Social, Brasília, 2011.

MUNDIM, P. S. "Um modelo para medir os efeitos da cobertura da imprensa no voto: teste nas eleições de 2002 e 2006". Opinião Pública, vol. 16, no 2, p. 394-425, 2010.

. "Imprensa e voto nas eleições presidenciais brasileiras de 2002 e 2006". Revista de Sociologia e Política, vol. 20, p. 123-147, 2012.

. "Cobertura da imprensa e eleições presidenciais de 2006: efeitos realmente limitados?". Revista Brasileira de Ciências Sociais, vol. 29, p. 91-107, 2014.

. "O viés da cobertura política da imprensa nas eleições presidenciais brasileiras de 2002, 2006 e 2010". Revista Brasileira de Ciência Política, no 25, p. 7-46, 2018. 
NOBLAT, R. "A 'greve geral' das corporações". Rio de Janeiro, 2017. Disponível em: <https://oglobo.globo.com/opiniao/a-greve-geral-das-corporacoes-21275018>. Acesso em: 30 jul. 2017.

O ESTADO DE S. PAULO, "Temer anuncia que cortará ponto de servidor grevista". São Paulo, ano 138, no 45117, p. A1, 27 abril 2017a.

. "A greve do feriadão". 27 abr. 2017b. Disponível em:

<https://opiniao.estadao.com.br/noticias/geral,a-greve-do-feriadao,70001753723>. Acesso em: 18 dez. 2019.

. "Nem greve, nem geral", São Paulo, 10 jul. 2017c. Disponível em:

<http://opiniao.estadao.com.br/noticias/geral,nem-greve-nem-geral,70001872780>. Acesso em: 20 jul. 2017.

O GLOBO. "Especialistas veem progresso e necessidade de reforma sindical", Rio de Janeiro, 28 abr. 2017a. Disponível em: <https://oglobo.globo.com/economia/especialistas-veem-progressonecessidade-de-reforma-sindical-21268628>. Acesso em: 10 ago. 2017.

. "Greve geral". Seção especial do website O Globo, Rio de Janeiro, 2017b. Disponível em: <https://oglobo.globo.com/economia/greve-geral/>. Acesso em: 30 jul. 2017.

. "Greve geral: direitos de consumidores e trabalhadores", Rio de Janeiro, 30 jun. 2017c. Disponível em: <https://oglobo.globo.com/economia/greve-geral-direitos-de-consumidorestrabalhadores-21266667>. Acesso em: 20 ago. 2017.

PORTO, M. P. "Frame diversity and citizen competence: towards a critical approach to news quality". Critical Studies in Media Communication, vol. 24, no 4, p. 303-321, 2007.

Media power and democratization in Brazil: TV Globo and the dilemmas of political accountability. New York: Routledge, 2012.

RALPH, N.; Birks M.; ChAPMAN, Y. "The methodological dynamism of grounded theory." International Journal of Qualitative Methods, vol. 14, no 4, 2015.

REIS, C. D. S. "Os bastidores da mídia e os movimentos sociais: o caso do MST". Tese de doutorado. Faculdade de Economia, Universidade de Coimbra, Coimbra, 2011.

Rubim, A. A. C.; Azevedo, F. A. "Mídia e política no Brasil: textos e agenda de pesquisa". Lua Nova: Revista de Cultura e Política, p. 189-216, 1998.

RuBIM, A; UFBA. Universidade Federal da Bahia. Faculdade de Comunicação. Mídia e eleições de 1998. João Pessoa, Paraíba, Brasil.

RUCHT, D. Research on social movements: the state of the art in Western Europe and the USA. Boulder, CO: Westview Press, 1991.

SCHEUfELE, D.A.; TEWKSBURY, D. "Framing, agenda setting, and priming: the evolution of three media effects models". Journal of Communication, vol. 57, p. 9-20, 2007.

SEABRA, C. "Greve no país fica esvaziada sem adesão de metroviários". São Paulo, 2017. Disponível em: <http://m.folha.uol.com.br/mercado/2017/06/1897270-greve-no-pais-fica-esvaziada-semadesao-de-metroviarios.shtml>. Acesso em: 20 ago. 2017.

Schaffner, F. J. (dir.). O Planeta dos Macacos (filme). Los Angeles: 20th Century Fox, 1968 (110min). 
SHAHIN, S., et al. "Protesting the paradigm: a comparative study of news coverage of protests in Brazil, China, and India". The International Journal of Press/Politics, vol. 21, n 2, p. 143-164, 2016.

SHOEMAKER, P. J. "Media treatment of deviant political groups". Journalism Quarterly, vol. 61, no 1 , p. $66-82,1984$.

SMITH, J., et al. "From protest to agenda building: description bias in media coverage of protest events in Washington, D.C.". Social Forces, vol. 79, no 4, p. 1.397-1.423, 2001.

SNow, D. A., et al. "Frame alignment processes, micromobilization, and movement participation". American Sociological Review, vol. 51, no 4, p. 464-481, 1986.

SouZA, M.; SILVA, U. C. "O MST no Jornal Hoje uma análise discursiva". Cadernos de Estudos Linguísticos, vol. 55, no 2, p. 177-192, 2013.

TRIVUNDŽA, I. T.; BRLEK, S. S. "Looking for Mr Hyde: the protest paradigm, violence and (de) legitimation of mass political protests". International Journal of Media \& Cultural Politics, vol. 13, no $1-2$, p. 131-148, 2017.

WEAVER, D. A.; SCACCO, J. M. "Revisiting the protest paradigm: the Tea Party as filtered through prime-time cable news". The International Journal of Press/Politics, vol. 18, no 1, p. 61-84, 2013.

$\mathrm{XU}, \mathrm{K}$. "Framing occupy Wall Street: a content analysis of the New York Times and USA today". International Journal of Communication, vol. 7, p. 2.412-2.432, 2013.

\section{Abstract}

The news coverage of the 2017 general strikes: protest paradigm or political slant

The protest paradigm is a concept widely used in the international literature in studies on the mass media's unfavorable treatment of political and social protests. There are three explanations for such treatment: (1) it varies depending on the ideological values of the media outlet (the more conservative, the higher the probability of adopting the paradigm of protest); (2) it varies depending on the position of the protest in relation to the status quo; and (3) it does not always occur. In this paper, we analyze the Brazilian media's coverage of the general strikes of 2017 against the Labor and Social Security reforms, examining the speeches and images associated with the groups involved in the general strikes in the publication Jornal Nacional and in the newspapers Folha de S. Paulo, O Estado de S. Paulo, and $O$ Globo. To this end, we implement the methodologies of framing analysis, image interpretation, and word clouds. The results confirm the occurrence of a protest paradigm in these cases and reveal five predominant ways of framing protests: (1) violence and vandalism; (2) selfish and disorganized action; (3) public disorder; (4) source of economic losses; and (5) lack of popular legitimacy. In conclusion, we reflect on this article's contribution to the international debate about the protest paradigm.

Keywords: media; protests; labor and social security reform; protest paradigm; federal government.

\section{Resumen}

La cobertura de las huelgas generales de 2017: paradigma de protesta o militancia política

El paradigma de protesta es un concepto ampliamente utilizado por la literatura internacional en los estudios del tratamiento dispensado por los grandes medios a manifestaciones políticas y sociales. Hay tres explicaciones para su ocurrencia: (1) varía con la orientación ideológica del medio (el más conservador, más probabilidades de adoptar el paradigma protesta); (2) varía con la posición de la protesta en relación al statu quo; y (3) no siempre ocurre. En este articulo analizamos la cobertura que grandes medios brasileños dieran a las huelgas generales de 2017 contra las reformas Laboral y Pensionaria, examinando los discursos e imágenes asociados a los grupos involucrados en las huelgas generales en el Jornal Nacional (televisión) y en los impresos Folha de S. Paulo, O Estado de S. Paulo y $O$ Globo. Para ello utilizamos las metodologías del análisis de encuadramiento, interpretación de imágenes y nubes de palabras. Los resultados confirman la ocurrencia de paradigma protesta en estos 
casos y revelan cinco formas predominantes de la formulación de las huelgas: (1) la violencia y el vandalismo, (2) egoísta, acción desorganizada, (3) el trastorno al espacio público, (4) Asociación retraso y (5) ausencia de legitimidad popular. En la conclusión reflexionamos sobre la contribución del presente trabajo al debate internacional sobre el tema.

Palabras clave: medios; huelgas; reforma laboral y de pensiones; paradigma de protesta; gobierno federal.

\section{Résumé}

La couverture des grèves générales de 2017: paradigme de la protestation ou militantisme politique

Le paradigme de protestation est un concept largement utilisé dans la littérature internationale, dans les études sur la façon dont les médias traditionnels traitent les manifestations politiques et sociales. Il y a trois explications à son apparition: (1) il varie selon I'orientation idéologique du milieu (plus celui-ci est conservateur, plus il est probable qu' on adopte le paradigme de protestation); (2) il varie selon la position de la protestation envers le statu quo; et (3) il ne se produit pas toujours. Dans cet article, nous avons examiné la couverture que les grands médias brésiliens ont fait des grèves générales de 2017 contre les réformes du travail et des retraites, l'examen des discours et des images associées aux groupes impliqués dans les grèves générales dans le Jornal National à la télevision et dans trois journaux, Folha de S. Paulo, O Estado de S. Paulo et O Globo. Pour cela, nous utilisons les méthodologies de l'analyse de l'encadrement, de l'interprétation de l'image et des nuages de mots. Les résultats confirment l'apparition de paradigme de protestation dans ces cas et ils révèlent cinq façons prédominantes d'encadrer les grèves: (1) la violence et le vandalisme, (2) I'action égoïste et désorganisée, (3) les troubles de l'espace public, (4) la source de préjudices à l'économie et (5) le manque de légitimité populaire. En conclusion, nous réfléchissons à la contribution de ce document au débat international sur le sujet.

Mots-clés: médias; grèves; réforme du travail et des retraites; paradigme de la protestation; gouvernement fédéral.

Artigo submetido à publicação em 15 de maio de 2018 . Versão final aprovada em 3 de dezembro de 2019.

Opinião Pública adota a licença Creative Commons CC-BY. 